\title{
Denervation Does Not Alter the Number of Neuronal Bungarotoxin Binding Sites on Autonomic Neurons in the Frog Cardiac Ganglion
}

\author{
Peter B. Sargent, Guy K. Bryan, ${ }^{a}$ Laura C. Streichert, ${ }^{b}$ and Evelyn N. Garrett \\ Departments of Stomatology (Oral Biology) and Physiology and the Neuroscience Program, University of California, \\ San Francisco, California 94143-0512
}

The binding of neuronal bungarotoxin (n-BuTX; also known as bungarotoxin 3.1, $k$-bungarotoxin, and toxin F) was analyzed in normal and denervated parasympathetic cardiac ganglia of the frog Rana pipiens. $n$-BuTX blocks both EPSPs and $A C h$ potentials at 5-20 nM, as determined by intracellular recording techniques. Scatchard analysis on homogenates indicates that cardiac ganglia have two classes of binding sites for ${ }^{125} \mid-n-B u T X:$ a high-affinity site with an apparent dissociation constant $\left(K_{d, a p p}\right)$ of $1.7 \mathrm{~nm}$ and a $B_{\max }$ (number of binding sites) of $3.8 \mathrm{fmol} / \mathrm{ganglion}$ and a low-affinity site with a $K_{\text {dapp }}$ of $12 \mu \mathrm{M}$ and a $B_{\max }$ of $14 \mathrm{pmol} / \mathrm{ganglion}$. $\alpha$-Bungarotoxin does not appear to interfere with the binding of ${ }^{125} \mid-n-B u T X$ to either site. The high-affinity binding site is likely to be the functional nicotinic $A C h$ receptor (AChR), given the similarity between its affinity for ${ }^{125} \mid-n-B u T X$ and the concentration of $n-B u T X$ required to block AChR function.

Light microscopic autoradiographic analysis of ${ }^{125}-n-B u T X$ binding to the ganglion cell surface reveals that toxin binding is concentrated at synaptic sites, which were identified using a synaptic vesicle-specific antibody. Scatchard analysis of autoradiographic data reveals that ${ }^{125} \mid-n$-BuTX binding to the neuronal surface is saturable and has a $K_{\mathrm{d}, \mathrm{app}}$ similar to that of the high-affinity binding site characterized in homogenates. Surface binding of ${ }^{125} \mid-n-B u T X$ is blocked by nicotine, carbachol, and $d$-tubocurarine $\left({ }^{2} C_{50}<20 \mu \mathrm{M}\right)$, but not by atropine $\left({ } C_{50}>10 \mathrm{~mm}\right)$.

Denervation of the heart increases the ACh sensitivity of cardiac ganglion cells but has no effect upon the number of high-affinity binding sites for ${ }^{125} \mid-n-B u T X$ in tissue homogenates. Moreover, autoradiographic analysis indicates that denervation does not alter the number of ${ }^{125} \mid-n-B u T X$ binding sites on the ganglion cell surface. $n-B u T X$ is as effective in reducing ganglion cell responses to $\mathrm{ACh}$ in denervated ganglia as it is in normally innervated ganglia.

\footnotetext{
Received Apr. 25, 1991; revised June 13, 1991; accepted June 24, 1991.

This work was supported by NIH Grant NS 24207, by Biomedical Research Support Grant RR 5305, and by funds awarded by the Academic Senate at UCSF. We thank Danny $Z$. Pang and Dianne Aspel for their participation in preliminary experiments, Donna Munoz O'Regan for technical assistance, and Vinny Chiappinelli, Stan Froehner, Ralph Loring, and Robert Meckler for reviewing a preliminary version of the manuscript.

Correspondence should be addressed to Dr. Peter B. Sargent, Division of Oral Biology, HSW-604, University of California, San Francisco, CA 94143-0512.

- Present address: Department of Biology, B-022, University of California at San Diego, La Jolla, CA 92093.

b Present address: Institute of Neuroscience, University of Oregon, Eugene, OR 97403.
}

Copyright (C) 1991 Society for Neuroscience $0270-6474 / 91 / 113610-14 \$ 05.00 / 0$
These results suggest that denervation alters neither the total number of nicotinic AChRs in the cardiac ganglion nor the number found on the surface of ganglion cells. These autonomic neurons thus respond differently to denervation than do skeletal myofibers. The increase in ACh sensitivity displayed by cardiac ganglion cells upon denervation cannot be explained by changes in AChR number.

The number and properties of nicotinic ACh receptors (AChRs) in skeletal muscle are regulated by innervation. Normally, AChRs are restricted to the synaptic membrane, which occupies approximately $0.1 \%$ of the myofiber surface. Removal of the influence of the motor axon, brought about by denervation, leads to the appearance of AChRs over the entire cell surface and to a 20-fold increase in the total number of surface AChRs (Hartzell and Fambrough, 1972). The emergence of extrajunctional AChRs leads to an increased ACh sensitivity (denervation supersensitivity) of the myofiber. Denervation does not alter the AChR density at the original synaptic site, which remains stable for weeks in the absence of innervation (Frank et al., 1975; Porter and Barnard, 1975). Denervation thus has differential effects on AChR density in synaptic and extrasynaptic regions of the myofiber.

Denervation of amphibian cardiac ganglia results in an increase in sensitivity of parasympathetic neurons to iontophoretically applied ACh (Kuffler et al., 1971; Roper, 1976; Dennis and Sargent, 1979). However, denervation supersensitivity is not universally observed in autonomic ganglia (Dunn and Marshall, 1985; McEachern et al., 1989), and studies by Berg and colleagues suggest that denervation of chick ciliary ganglia reduces the total number of AChRs as well as the mRNA levels for its $\alpha$-subunit (Jacob and Berg, 1987, 1988; Boyd et al., 1988). We therefore examined the effects of denervation upon AChR number in the frog cardiac ganglion in order to learn whether changes in AChR number can explain denervation supersensitivity in this system. We found that denervation did not change the number of binding sites on the surface of cardiac ganglion cells to neuronal bungarotoxin (n-BuTX), a snake toxin that blocks AChR function. This indicates that denervation supersensitivity in the cardiac ganglion cannot be explained by an increase in AChR number. Our results suggest that neurons and myofibers respond differently to denervation.

Some of this work has been published previously in abstract form (Sargent and Bryan, 1989).

\section{Materials and Methods}

Animals and surgery. Adult Rana pipiens (northern variety) of either sex and having a body length of 5-7 $\mathrm{cm}$ were obtained from Hazen 
Frog Farm (Alburg, VT) and West Jersey Biological (Wenonah, NJ). The cardiac ganglion was denervated by resecting $1 \mathrm{~cm}$ lengths of the vagosympathetic nerves bilaterally (Kuffler et al., 1971). Cardiac ganglion cells are not reinnervated for at least $50 \mathrm{~d}$ following vagosympathetic nerve resection (Dennis and Sargent, 1979). Denervated animals were used 16-20 d after surgery, at a time when their acetylcholine sensitivity is maximal (Dennis and Sargent, 1979). Animals were housed at $22-24^{\circ} \mathrm{C}$ in tanks where they had access to both standing tap water and a dry platform. Animals were fed twice weekly; normal animals were given meal worms, while denervated ones were fed calves' liver.

Animals were killed by decapitation and pithing. The cardiac ganglion is embedded within the interatrial septum, which was removed along with attached cardiac branches of the vagosympathetic nerves as described by McMahan and Kuffler (1971). Dissections were done in frog Ringer's (114 mM NaCl, $2 \mathrm{~mm} \mathrm{KCl,} 1.8 \mathrm{~mm} \mathrm{CaCl}_{2}$, 2 mM HEPES, pH 7.4).

Neurophysiology. The cardiac ganglion contains approximately 1000 parasympathetic neurons lying singly and in clusters within the thin, transparent interatrial septum. The neuronal cell bodies are unipolar and are associated with the paired cardiac branches of the vagosympathetic nerves. The nerve trunks that course through the septum contain parasympathetic preganglionic axons and sympathetic postganglionic axons as well as the axons of the ganglion cells (McMahan and Kuffler, 1971).

Intracellular recordings were made in frog Ringer's containing 3.6$5.0 \mathrm{mM} \mathrm{CaCl}{ }_{2}$ and $2 \mathrm{mg} / \mathrm{ml}$ BSA. Calcium was elevated in order to stabilize the intracellular recordings, and BSA was added to saturate nonspecific binding sites for $\mathrm{n}$-BuTX present in the ganglion. Intracellular recordings were made with glass microelectrodes having an initial resistance of 75-150 M $\Omega$ and beveled to $50-80 \%$ of their initial resistance on a $0.3 \mu \mathrm{m}$ alumina surface. Recordings were made using an Axoclamp $2 \mathrm{~A}$ amplifier in the bridge mode. Voltage traces were digitized at $10 \mathrm{kHz}$, averaged over three trials in some instances, and stored on disk using a microcomputer with a Labmaster A/D board and pCLAMP software (Axon Instruments).

The cardiac branches of the vagosympathetic nerves were drawn into suction electrodes for stimulation. Only the principal input, which almost invariably generates a suprathreshold EPSP (Dennis and Sargent, 1978), was studied systematically. The stimulus strength was set to 1.5 times threshold for activating the principal input. Baseline data were collected for 10-15 min in Ringer's plus BSA; only neurons having a stable resting potential more negative than $-40 \mathrm{mV}$ and a directly elicited action potential at least $40 \mathrm{mV}$ in amplitude during this period were analyzed further. The extended recordings from each cell during toxin application and washout required additional criteria with respect to recording quality and cell viability. Input resistance and resting potential were monitored regularly. Cell viability was ascertained periodically by directly eliciting action potentials via the recording electrode; cells that did not continue to show a spike at least $40 \mathrm{mV}$ in amplitude were abandoned.

The effects of $\mathrm{n}$-BuTX and $\alpha$-bungarotoxin ( $\alpha$-BuTX) upon nerveevoked responses to acetylcholine were determined by recording intracellularly from individual neurons before, during, and after administration of the toxin. n-BuTX or $\alpha$-BuTX was added to the recording chamber by means of a perfusion system driven by a peristaltic pump, which permitted solutions to be changed without interruption of the recording. The flow rate was adjusted so that $95 \%$ of the bath volume was exchanged every $5 \mathrm{~min}$. During the application and washout of toxin, postsynaptic responses were sampled every 3-5 min. The effect of n-BuTX was assumed to have stabilized when EPSP size remained constant for 15 min, and washout of n-BuTX was initiated thereafter.

The effects of n-BuTX upon pipette-evoked responses to acetylcholine were assessed by measuring the average response of the cell to the prolonged application of $500 \mu \mathrm{M}$ acetylcholine in Ringer's pressure ejected from a pipette whose tip was placed $10 \mu \mathrm{m}$ from the cell surface. The acetylcholine pipette had a tip diameter of 1-2 $\mu \mathrm{m}$, and acetylcholine was applied with a pressure of 3-7 psi for long enough $(30 \mathrm{sec})$ to permit the response to desensitize to baseline. This method of application swiftly bathes the cell in a relatively uniform dose of transmitter and yields a measure of sensitivity that is proportional to the total number of functional AChRs on the cell surface. No attempt was made to record from individual cells for the duration of the toxin application and washout, but, rather, a few acctylcholine responses were obtained initially from each preparation to ensure that ganglion cells responded normally, after which the ganglion was incubated with $20 \mathrm{nM}$ n-BuTX for $3 \mathrm{hr}$ before additional measurements were made. Since the experiments on synaptically released acetylcholine suggested that the toxin's effect is only slowly reversible (see Results), a washout was not performed. Acetylcholine responses obtained from ganglion cells in untreated preparations did not decline significantly over 4-5 hr.

Neuronal bungarotoxin. Neuronal bungarotoxin was obtained from Biotoxins (St. Cloud, FL). An extinction coefficient of 0.832 at $280 \mathrm{~nm}$ for a $1 \mathrm{mg} / \mathrm{ml}$ solution was calculated by comparing the absorbance of a sample of the toxin with the results of subsequent quantitative amino acid analysis. An extinction coefficient of 0.832 is similar to the value of 0.816 reported by Chiappinelli and Lee (1985). n-BuTX exists in solution as a dimer (Chiappinelli and Lee, 1985), and a dimeric molecular weight of 14,600 was used in calculating toxin molarity.

n-BuTX was iodinated by the iodo-gen method as described by Chiappinelli et al. (1987). Briefly, $11 \mu \mathrm{g}$ of toxin was mixed with $1 \mathrm{mCi}$ of ${ }^{125} \mathrm{I}$ as sodium iodide in $\mathrm{H}_{2} \mathrm{O}$ (Amersham; $300-600 \mathrm{Ci} / \mathrm{mmol}$ ) in $90 \mu \mathrm{l}$ of solution containing $100 \mathrm{~mm}$ Na phosphate, $\mathrm{pH} 7.4$. The reaction was carried out in a $12 \times 100 \mathrm{~mm}$ glass tube in contact with $4.3 \mu \mathrm{g}$ of iodo-gen (Pierce), which had previously dried onto the glass surface at the bottom of the tube. The rcaction was allowed to proceed for $15 \mathrm{~min}$ at $22-24^{\circ} \mathrm{C}$, after which time $10 \mu \mathrm{l}$ of a saturated solution of tyrosine was added for an additional $5 \mathrm{~min}$. The reaction mixture was then loaded onto a disposable column containing $7 \mathrm{ml}$ of Sephadex G-10, through which had previously been passed $50 \mathrm{mg}$ of BSA in $100 \mathrm{~mm}$ Na phosphate, $\mathrm{pH} \mathrm{7.4}$, and a large volume of $100 \mathrm{~mm} \mathrm{Na}$ phosphate buffer alone. Column eluates were collected in $0.9 \mathrm{ml}$ fractions, and the third fraction typically contained $80-90 \%$ of the protein eluting from the column and $30-60 \%$ of the radioactivity initially present in the reaction mixture. Column runs with test samples of newly purified ${ }^{125}$ I-n-BuTX indicated that protein recovery during the reaction and column steps was $75-80 \%$. Specific activity of the ${ }^{125}$ I-n-BuTX generated according to this procedure was in the range of $500-1200 \mathrm{Ci} / \mathrm{mmol}$.

Binding studies. The binding of ${ }^{125} \mathrm{I}-\mathrm{n}-\mathrm{BuTX}$ was assessed in homogenates of the nerve trunks dissected from interatrial septa. Typically, the two nerve trunks from each of 12 septa were removed and pooled for a single experiment. The trunks were homogenized in a ground glass homogenizer in a final volume of $600 \mu \mathrm{l}$ in Ringer's containing $2 \mathrm{mg} /$ ml BSA (abbreviated RB). In some experiments, the tissue was homogenized in protease inhibitors (1 mM EDTA, $1 \mathrm{~mm}$ EGTA, $1 \mathrm{~mm}$ phenylmethylsulfonyl fiuoride, $1 \mathrm{~mm}$ iodoacetic acid, $10 \mu \mathrm{g} / \mathrm{ml}$ leupeptin). The presence of the inhibitors did not noticeably alter the results of the binding studies, and they were usually omitted.

Binding experiments were carried out generally as described by Wolf et al. (1988). Homogenate and ${ }^{125} I-n-B u T X$ were mixed, with or without $a \geq 100$-fold excess of unlabeled n-BuTX, for $4 \mathrm{hr}$ at $22-24^{\circ} \mathrm{C}$ in a final volume of $50 \mu \mathrm{l}$ in a microcentrifuge tube. The reaction was terminated by the addition of $600 \mu \mathrm{l}$ of ice-cold RB and centrifugation in a microcentrifuge for $5 \mathrm{~min}$ at $11,000 \times \mathrm{g}$. The pellets were washed in an additional $600 \mu \mathrm{l}$ of ice-cold RB, resedimented, and counted in a gamma counter at $75-80 \%$ efficiency. Nonspecific binding produced pellets having $\cong 0.1 \%$ of the isotope present in the initial incubation mixture. Experiments were done using 11-12 concentrations of ${ }^{125}$ I-n-BuTX, ranging from 0.44 to $120 \mathrm{nM}$ (evenly spaced logarithmically). Two assay tubes were run for each concentration, one with and one without unlabeled n-BuTX. Binding in excess of that in the presence of $a \geq 100$ fold surplus of unlabeled n-BuTX was considered to be specific. The concentration of free ${ }^{125} \mathrm{I}-\mathrm{n}$-BuTX is not reduced by more than a few percent during the reaction, and thus the reaction is pseudo-first order. The specific binding is directly proportional to amount of homogenate up to at least $125 \%$ of the amount typically used.

Protein assays were performed using the bicinchoninic assay (Pierce), with BSA as a standard.

Estimates of apparent $K_{d}\left(K_{d, \mathrm{app}}\right)$ and number of binding sites $\left(B_{\max }\right)$ were made by subjecting plots of specific binding versus concentration to a double rectangular curve-fitting procedure using INPLOT software (GraphPad) and a microcomputer. In most instances, the best fits appeared satisfactory when transformed into "Bound/Free" versus "Bound" and compared to the transformed raw data. In some instances, however, the fitted values were further refined; any change that improved the fit visually and increased the number of runs of residuals (Sokal and Rohlf, 1981) was deemed acceptable.

Autoradiography. Light microscopic autoradiography was performed on plastic sections as described by Burden et al. (1979). Intact, unfixed interatrial septa were preincubated with $\mathrm{RB}$ for $20 \mathrm{~min}$ and then with $20 \mathrm{nM}{ }^{125} \mathrm{I}-\mathrm{n}-\mathrm{BuTX}$ in RB for $2 \mathrm{hr}$. Two hours was chosen since the 


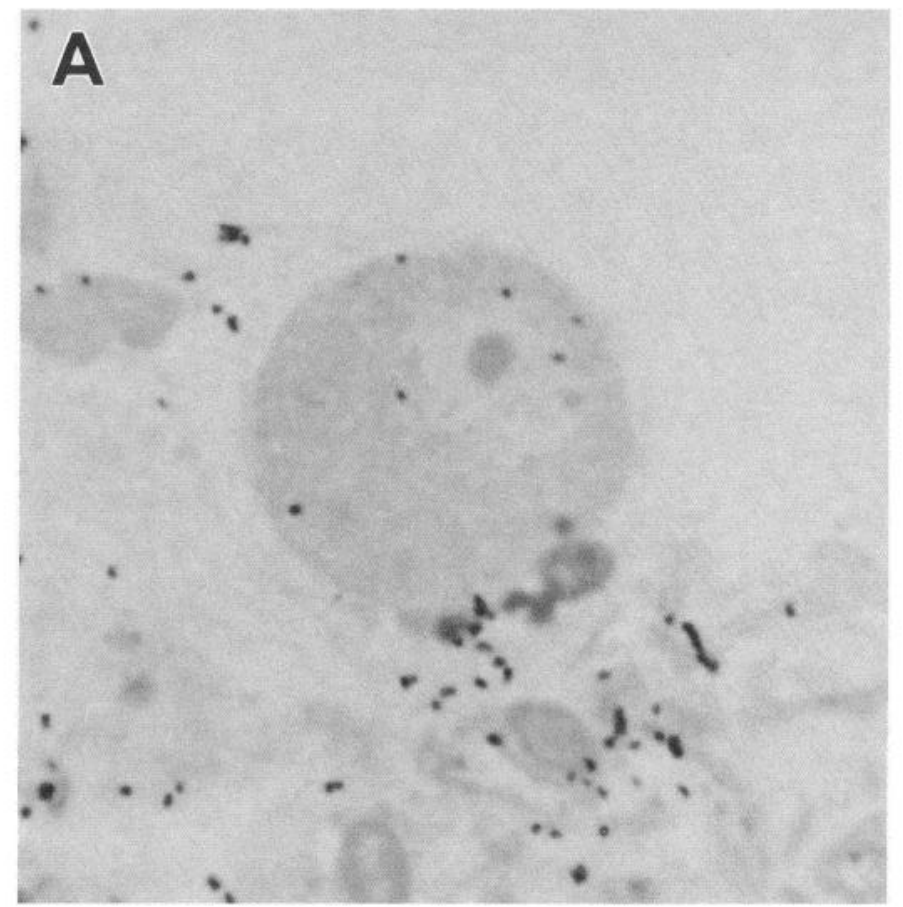

B

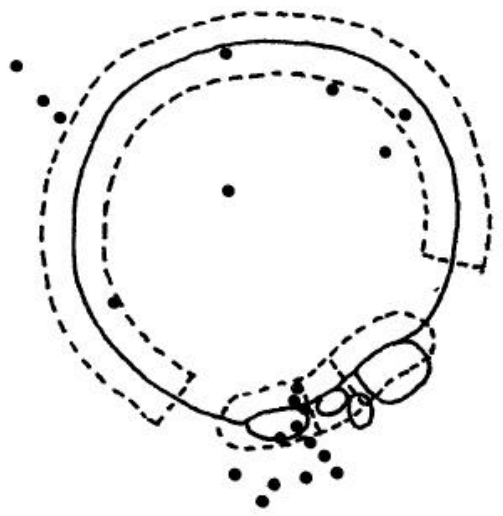

$10 \mu \mathrm{m}$

Figure 1. Micrograph $(A)$ and camera lucida drawing $(B)$ of a cardiac ganglion cell, with three immunocytochemically stained boutons drawn on its surface and with autoradiographic grains indicated by dots (a fourth bouton was not considered to be in contact with the ganglion cell surface in this section). The micrograph was taken by double exposure, with one focal plane at the plastic section to image the tissue and one focal plane in the emulsion to image the grains. Extrasynaptic grain density was calculated by counting grains falling within $2 \mu \mathrm{m}$ of the cell perimeter over regions of the membrane at least $6 \mu \mathrm{m}$ from the nearest bouton (within the dashed "window" lying over extrasynaptic membrane). Grains were assumed to arise from a bouton if they fell within $2 \mu \mathrm{m}$ of the synaptic membrane (within the dashed oval windows lying over the boutons). The grain density at synaptic boutons was calculated by subtracting the expected contribution of extrasynaptic grains falling within the synaptic window from the actual number of grains, and by then dividing by the length of the synaptic membrane (thus, [GR - (EGD)(SL + 4)]/SL, where GR is the number of grains, pharmacological effects of n-BuTX had usually stabilized by this time. The degree of nonspecific binding was assessed in septa analyzed in parallel that were pre- and coincubated with $2 \mu \mathrm{M}$ unlabeled n-BuTX. Unbound ${ }^{125} \mathrm{I}-\mathrm{n}$-BuTX was removed by washing in several volumes of RB for 10 min and in Ringer's for an additional 5 min, after which bound ${ }^{125} \mathrm{I}-\mathrm{n}$-BuTX was immobilized by fixing the tissue with $1 \%$ form-

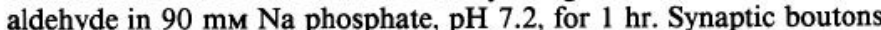
were then visualized immunocytochemically using an anti-synaptic vesicle antibody (ASV48; Matthew et al., 1981) in conjunction with the avidin-biotinylated horseradish peroxidase $(\mathrm{ABC})$ technique (Sargent, 1983). Tissue was postfixed for $15 \mathrm{~min}$ in $0.1 \% \mathrm{OsO}_{4}$ in $60 \mathrm{~mm} \mathrm{Na}$ phosphate, pH 7.2, dehydrated in ethanol, and embedded in EponAraldite. Semithin plastic sections $(0.5 \mu \mathrm{m})$ containing areas of the tissue rich in cell bodies were mounted on subbed glass slides, which were then dipped in Kodak NTB-2 emulsion (diluted 1:1 in 2\% glycerol) and stored desiccated at $4^{\circ} \mathrm{C}$ for 2-8 weeks. Slides were developed in Kodak D-19 developer for 2 min, fixed in Kodak Rapid Fix, and counterstained in $1 \%$ toluidine blue in $1 \% \mathrm{Na}$ borate. Analysis of the distribution and density of autoradiographic grains near the cell surface was performed after camera lucida drawings were made of the perimeter of each ganglion cell, along with the stained synaptic boutons on its surface (if any were present) and the position of the grains.

Autoradiographic grain density over the neuronal surface was assessed by counting all grains falling within $2 \mu \mathrm{m}$ of the surface. Roughly $50 \%$ of grains arising from a line source fall within $2 \mu \mathrm{m}$ of the line (Burden et al., 1979). Casual observation of autoradiograms suggested that grain density over synaptic sites was considerably greater than that over extrasynaptic sites and that many grains over the perisynaptic surface in fact arose from synaptic sites. Therefore, all grains falling within a window that extends laterally $2 \mu \mathrm{m}$ beyond the lateral edge of the synaptic membrane were scored as having arisen from synaptic sites (Fig. 1). Some of the grains falling within the window presumably arise from the extrasynaptic surface, however, and an appropriate correction was therefore made (details provided in Fig. 1, caption). Extrasynaptic grain density was measured over regions of the surface at least $6 \mu \mathrm{m}$ distant from the nearest bouton in the plane of section (Fig. 1). Grain clusters were defined as occurring whenever the number of grains falling within a window appropriate for an average-sized bouton exceeded five times the mean surface grain density for all cells in the set. Thus, if the average bouton length for a set of normal cells incubated with ${ }^{125}$ I-n-BuTX cells were $4.0 \mu \mathrm{m}$, and if the mean surface grain density for those cells were $0.16 / \mu \mathrm{m}$, then at least seven grains would have to fall within an $8 \mu \mathrm{m}$ length of perimeter in order for them to be scored as a cluster $(8 \mu \mathrm{m}=$ $4 \mu \mathrm{m}+2 \mu \mathrm{m}$ on either side).

Thirty cell profiles were examined for each condition (e.g., normal experimental, normal control, denervated experimental, denervated control), and an overall mean grain density for synaptic, extrasynaptic, and total membrane was measured. Values for grain density obtained in the presence of an excess of unlabeled n-BuTX (control) were subtracted from those in its absence (experimental) to yield a measure of specific binding. Specific grain density was compared in normal and denervated ganglia by treating ganglia identically through all phases of the procedure, from incubations to embedding (eight experiments, with approximately 120 cells analyzed per experiment).

Statistics. Values are given as the mean $\pm \mathrm{SD}$, unless otherwise indicated. Means were compared by the Student's $t$ test or, when there was some concern regarding whether the samples were normally distributed, by the Mann-Whitney test (unpaired) or the Wilcoxon signed rank test (paired). $p$ values given in the text were calculated using the $t$ test unless otherwise indicated.

\section{Results}

\section{Effects of $n$-BuTX on AChR function}

Stimulation of the principal input to cardiac ganglion cells results in a large, suprathreshold EPSP that evokes a single action potential (Fig. $2 A 1-C I$ ). The afterdepolarization following the

\footnotetext{
SL is the length of bouton contact, and EGD is the average extrasynaptic grain density for all cells in the same experimental group). Grain density for synaptic sites, for extrasynaptic membrane, and for the entire cell was calculated for each cell, and then means were computed from approximately 30 cells in each experimental group.
} 
5 nM n-BuTX

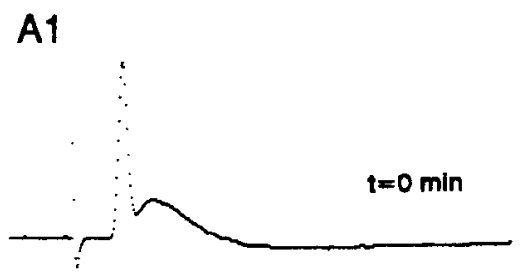

A2

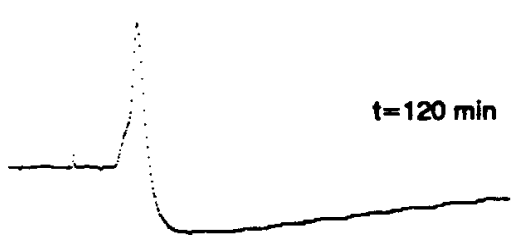

A3

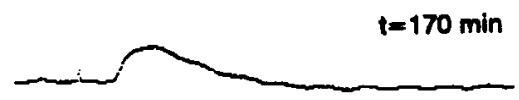

A4

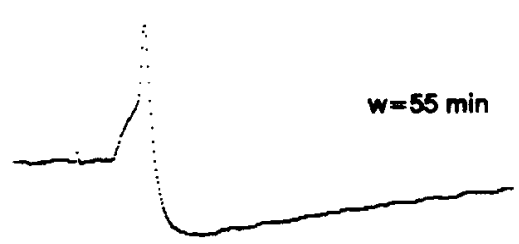

20 nM n-BuTX

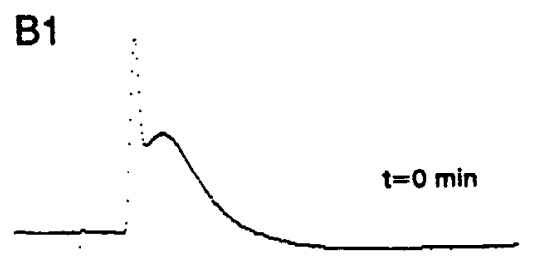

B2

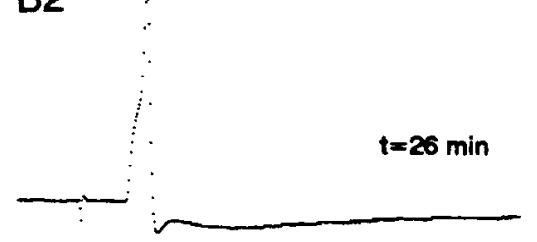

B3

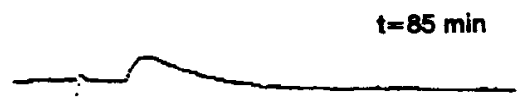

B4

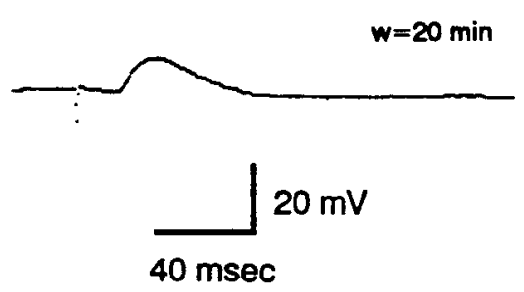

$300 \mathrm{nM} \alpha$-BuTX

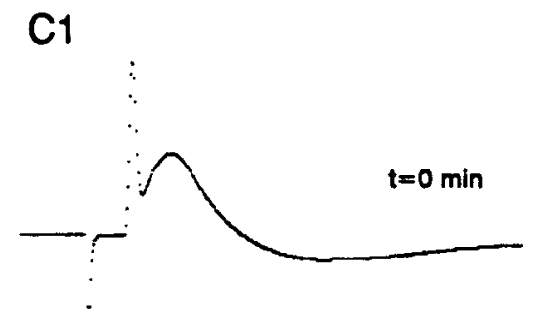

C2

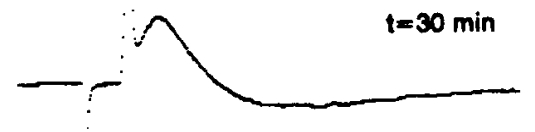

C3

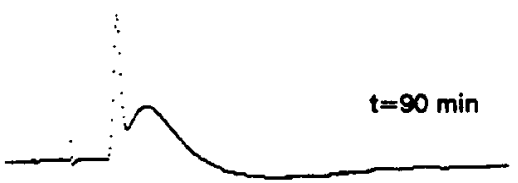

C4

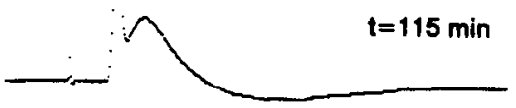

Figure 2. Effect of n-BuTX and $\alpha$-BuTX on synaptic transmission in the cardiac ganglion. EPSPs were monitored from individual neurons before, during, and after bath application of n-BuTX $(A, B)$ or $\alpha$-BuTX $(C)$. Action potentials appear as dots, since traces are digitized. The top trace in each column $(t=0 \mathrm{~min})$ was taken before the addition of toxin. Numbers above the baseline in the other traces indicate time in minutes after exposure to toxin (indicated by a $t$ ) or after washout of toxin (indicated by a $w$ ). Each trace is the average of three responses. n-BuTX blocked transmission, while $\alpha$-BuTX did not.

action potential is the result of prolonged transmitter action (Dennis et al., 1971). At either 5 or $20 \mathrm{nM}$, n-BuTX gradually diminished the size of the afterdepolarization and then reduced the EPSP to subthreshold levels (Fig. $2 A 3, B 3$ ). n-BuTX did not alter either the resting potential or the input resistance $(p>$ 0.5 ). n-BuTX blocked synaptic transmission in a dose-dependent manner. n-BuTX at 1-2 nм did not reduce EPSPs to subthreshold levels, while $5 \mathrm{~nm}$ and $20 \mathrm{~nm} \mathrm{n}$-BuTX reduced EPSP size to $7.9 \pm 1.5 \mathrm{mV}(n=4)$ and $3.9 \pm 1.7 \mathrm{mV}(n=5)$, respectively ( $20 \mathrm{~nm}$ mean significantly different from $5 \mathrm{~nm}$ mean, $p=0.016$ ).

The effect of n-BuTX typically took 1-2 hr to stabilize. Some reversibility in the effect of $n$-BuTX was noted following its removal; in a few instances, the EPSP once again became suprathreshold (Fig. 2A4). An absolute limit of $\cong 4 \mathrm{hr}$ in the time during which recordings could be maintained from individual cells prevented us from obtaining a complete block and washout curve for a single cell. Nevertheless, the reversibility in the effect of n-BuTX observed even after $1 \mathrm{hr}$ suggests that it dissociates from AChRs more readily than does $\alpha$-BuTX from muscle AChRs.

Figure $2 C$ illustrates a typical result of applying $\alpha$-BuTX to the cardiac ganglion. $\alpha$-BuTX did not affect synaptic transmission in the cardiac ganglion at concentrations as high as $300 \mathrm{nM}$ $(n=3)$. The $\alpha$-BuTX experiments demonstrate that ganglion cells respond to nerve stimulation for extended periods of time, and hence the effects of n-BuTX cannot be explained by a loss of viability.

n-BuTX significantly reduced the amplitude of ganglion cell responses to pipette-released $\mathrm{ACh}$. The mean response to application of $500 \mu \mathrm{M}$ ACh was $8.8 \pm 5.1 \mathrm{mV}(n=14)$ normally and $2.0 \pm 1.1 \mathrm{mV}(n=11)$ in the presence of $20 \mathrm{nM} \mathrm{n}$-BuTX 

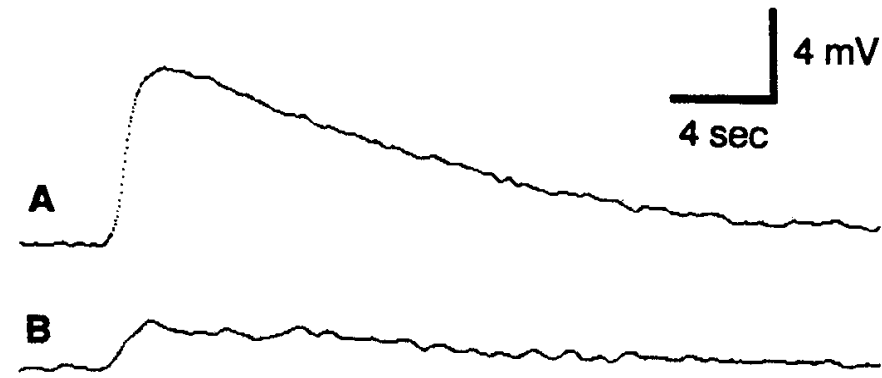

C

Figure 3. Responses of denervated cardiac ganglion cells $(A, B)$ to the sustained application of ACh $(C) . A$ and $B$ show responses obtained in $\mathrm{RB}$ and in RB containing $20 \mathrm{nM} \mathrm{n}-\mathrm{BuTX}$, respectively. Each trace is a single response. $C$ shows the application of pressure to the $A C h$ pipette. n-BuTX significantly reduced the response of cardiac ganglion cells to ACh.

$(p=0.0002)$. This indicates that $n-B u T X$ acts directly on AChRs and that its effect upon synaptic transmission can be explained by a postsynaptic action. Denervation led to an approximately twofold increase in ACh sensitivity, from $8.8 \pm 5.1 \mathrm{mV}(n=$ 14) to $15.9 \pm 6.6 \mathrm{mV}(n=18 ; p=0.003)$, confirming the presence of denervation supersensitivity in the cardiac ganglion (Kuffler et al., 1971; Roper, 1976; Dennis and Sargent, 1979; Streichert and Sargent, 1991). n-BuTX also blocks ACh responses on denervated ganglion cells; the mean response of denervated neurons to $500 \mu \mathrm{M}$ ACh was $15.9 \pm 6.6 \mathrm{mV}(n=$ 18), while in the presence of $20 \mathrm{nM} \mathrm{n-BuTX}$ it was $1.9 \pm 1.6$ $\mathrm{mV}(n=11 ; p<0.0001)$. Figure 3 shows typical ACh responses from a denervated neuron $(A)$ and from another denervated neuron incubated for $3 \mathrm{hr}$ with $20 \mathrm{nM} \mathrm{n}-\mathrm{BuTX}(B)$.

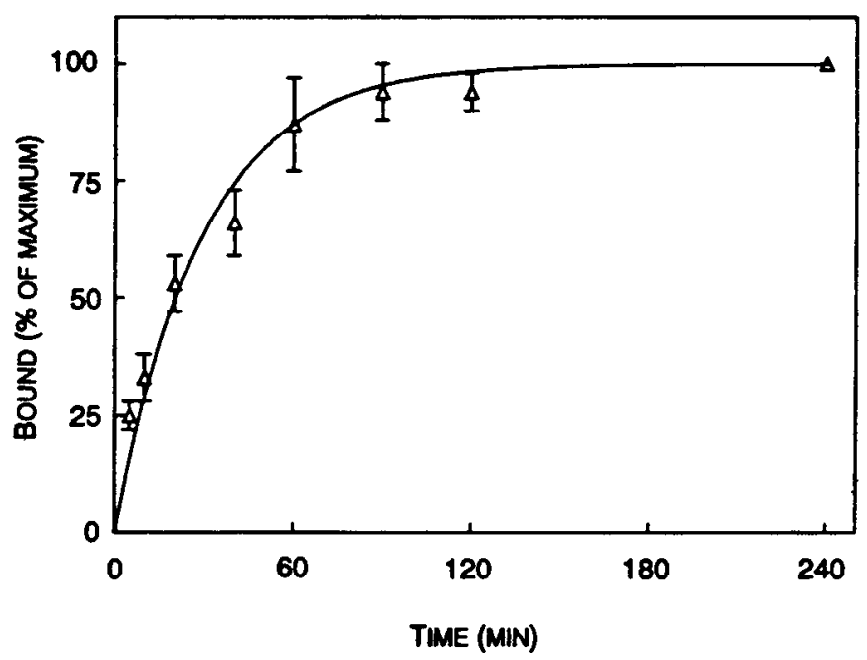

Figure 4. Binding of $5 \mathrm{nM}{ }^{125} \mathrm{I}-\mathrm{n}-\mathrm{BuTX}$ to homogenates of cardiac ganglia reaches equililbrium in approximately $4 \mathrm{hr}$. In seven experiments, the binding at various time intervals was determined in duplicate and is expressed as a fraction of the binding at $4 \mathrm{hr}$. Data points are the mean \pm SE for three to seven determinations. The fitted curve assumes a simple exponential association with a rate constant of 0.034 $\left(t_{1,2}=20 \mathrm{~min}\right)$.
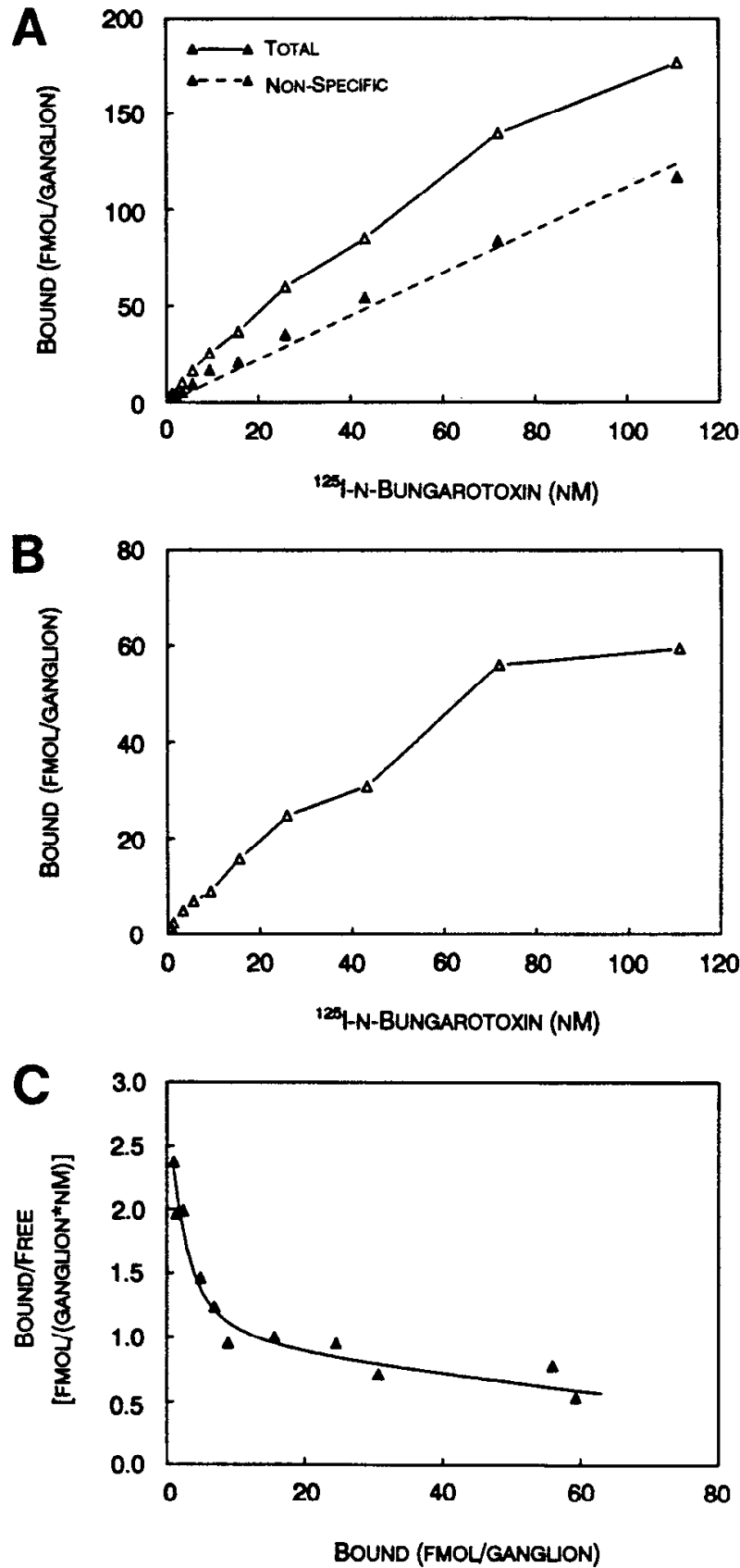

Figure 5. Binding of ${ }^{125} \mathrm{I}-\mathrm{n}$-BuTX to homogenates of the cardiac ganglia displays two classes of binding sites. $A$ shows an example of total (solid line) and nonspecific (broken line) binding of ${ }^{125}$ I-n-BuTX (11 concentrations of ${ }^{125}$ I-n-BuTX). The specific binding, obtained by subtracting nonspecific from total data, does not appear to saturate at concentrations of ${ }^{125} \mathrm{I}-\mathrm{n}-\mathrm{BuTX}$ as high as $120 \mathrm{nM}(B)$. The specific binding data, when transformed $(C)$, indicate the presence of two classes of binding sites. The best fit to the data (curved line) assumes $K_{\text {d.apo }}$ and $B_{\max }$ values given in the Results.

\section{Binding of ${ }^{125} I-n-B u T X$ to homogenates of cardiac ganglia}

The blockade of AChR function by nanomolar concentrations of n-BuTX suggests that toxin binding should be measurable both biochemically and autoradiographically. Specific binding of ${ }^{125} I-n-B u T X$ to crude homogenates of cardiac ganglia showed saturation in approximately $4 \mathrm{hr}$ at $22-24^{\circ} \mathrm{C}$ (Fig. 4). In a typical experiment, homogenates incubated for $4 \mathrm{hr}$ with varying concentrations of ${ }^{125} \mathrm{I}-\mathrm{n}-\mathrm{BuTX}$ displayed nonspecific binding that 


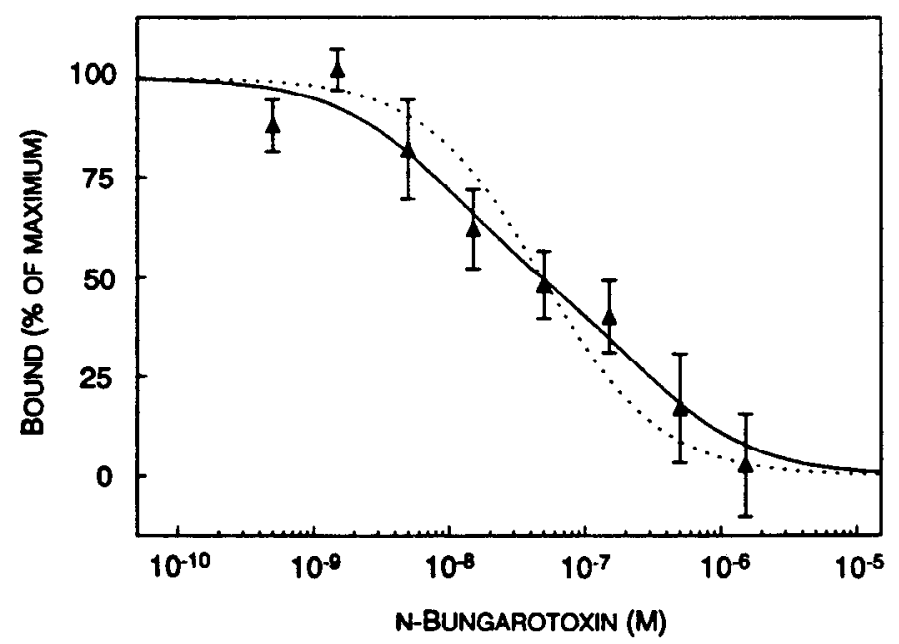

Figure 6. Effect of unlabeled n-BuTX upon binding of $5 \mathrm{nM}{ }^{125} I-\mathrm{n}$ Bu I X to homogenates of cardiac ganglia. Data are mean $\pm S E$ for three determinations. The broken line is the best fit of the data assuming a single component of inhibition, and the solid line is the best fit assuming a pair of components. For both fits, the minima and maxima were forced to be $0 \%$ (binding in the presence of $5 \mu \mathrm{M} \mathrm{n}$-BuTX) and $100 \%$ (binding in the absence of $\mathrm{n}-\mathrm{BuTX}$ ), respectively. The fit is improved by assuming that there are two components of inhibition (see Results for details).

was linear with concentration (Fig. $5 A$, broken line) and specific binding that did not appear to saturate at concentrations as high as $120 \mathrm{nM}$ (Fig. 5B). Scatchard analysis of the data shows two distinct classes of binding sites (Fig. $5 C$ ); in this experiment the high-affinity site was estimated to have a $K_{d, \text { app }}$ of $1.3 \mathrm{~nm}$ and a $B_{\max }$ of $2.4 \mathrm{fmol} / g a n g l i o n$, and the low-affinity binding site, a $K_{d, \text { app }}$ of $180 \mathrm{nM}$ and a $B_{\max }$ of $160 \mathrm{fmol} /$ ganglion. The average values for these parameters obtained in seven separate assays were, for the high-affinity site, a $K_{d, \mathrm{app}}$ of $1.7 \pm 1.1 \mathrm{nM}$ and a $B_{\max }$ of $3.8 \pm 2.8 \mathrm{fmol} /$ ganglion and, for the low-affinity site, a $K_{d, \text { app }}$ of $12 \pm 12 \mu \mathrm{M}$ and a $B_{\max }$ of $14 \pm 15 \mathrm{pmol} /$ ganglion. The estimates of $K_{d, \mathrm{app}}$ and $B_{\max }$ for the low-affinity binding site are particularly unreliable; in three experiments the $K_{d . a p d}$ and the $B_{\max }$ were in the range of 50-200 nM and 50-200 fmol/ganglion, respectively (as in Fig. 5), while in the remaining four experiments the estimates for both parameters exceeded 10,000. The presence of two classes of binding sites cannot be attributed to negative cooperativity in a single class of receptors, since the rate of dissociation of the ${ }^{125} \mathrm{I}-\mathrm{n}$-BuTX from its binding sites was similar in the presence and the absence of an excess of unlabeled n-BuTX (data not shown).

Normal ganglia contained an average of $31 \pm 20 \mu \mathrm{g}$ of protein $(n=6)$, and so the $B_{\max }$ values are $0.12 \mathrm{fmol} / \mu \mathrm{g}$ protein for the high-affinity site and $0.45 \mathrm{pmol} / \mu \mathrm{g}$ protein for the low-affinity site.

A second method for estimating the affinity of n-BuTX for its binding sites within tissue homogenates was to study the ability of unlabeled n-BuTX to displace the binding of $5 \mathrm{~nm}$ ${ }^{125}$ I-n-BuTX under equilibrium conditions (Fig. 6). The displacement of ${ }^{125} \mathrm{I}-\mathrm{n}$-BuTX binding was fit with two different inhibition isotherms, one having a single component (broken line) and one having two components (solid line). The coefficient of correlation $(r)$ was 0.956 for the single component fit $(p=$ $0.00006, \mathrm{df}=7)$ and 0.985 for the dual component fit $(p=$ $0.00005, \mathrm{df}=5$ ). Since the $p$ value is slightly decreased when two components are used, despite the loss of two degrees of

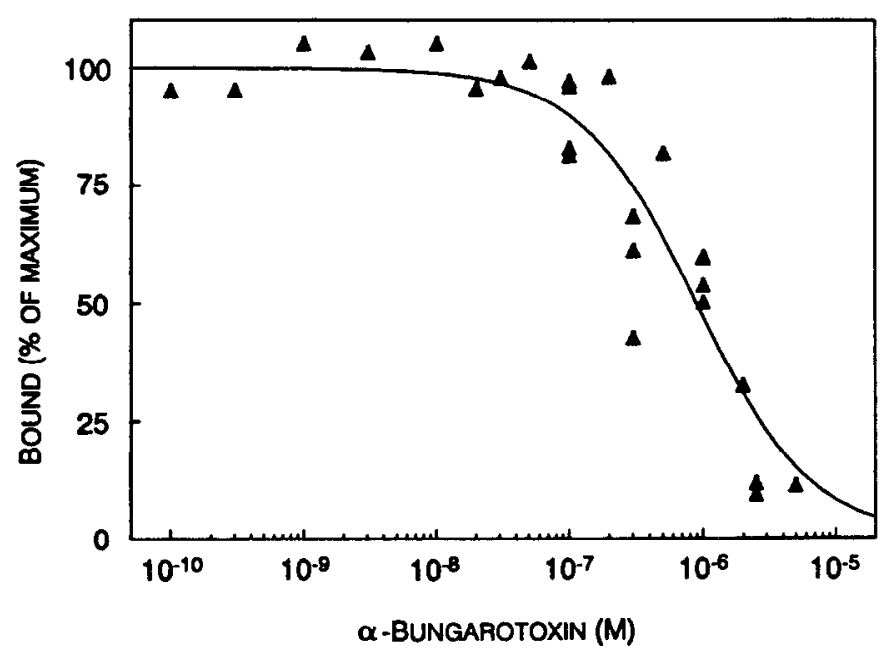

Figure 7. Effect of $\alpha$-BuTX upon binding of ${ }^{125} \mathrm{I}-\mathrm{n}$-BuTX to homogenates of cardiac ganglia. Solid line is best fit of the data, assuming a single component of binding with a Hill coefficient of $1.0(r=0.931)$.

freedom, the dual component fit is considered superior. The $K_{d}$ for the two components of inhibition is $2.4 \mathrm{~nm}$ for the highaffinity site and $70 \mathrm{~nm}$ for the low-affinity site (calculated assuming a $K_{d}$ for ${ }^{125} \mathrm{I}-\mathrm{n}$-BuTX binding of $1.7 \mathrm{nM}$ ). The estimated $K_{d}$ for the high-affinity site recognized by unlabeled n-BuTX, $2.4 \mathrm{~nm}$, is similar to the previous estimate of $1.7 \mathrm{~nm}$ for this site, based on the binding of ${ }^{125} \mathrm{I}$-n-BuTX. This suggests that iodination does not markedly alter the affinity of n-BuTX for this site. The estimated $K_{d}$ for the low-affinity site, $70 \mathrm{nM}$, is considerably smaller than estimates based on binding to this site of ${ }^{25}$ I-n-BuTX but is likely to be more reliable than those estimates, since a wider range of unlabeled toxin concentrations was used in the titration experiments than in the Scatchard experiments.

The binding of ${ }^{25} \mathrm{I}-\mathrm{n}$-BuTX to tissue homogenates was not affected by $\alpha$-BuTX until $\alpha$-BuTX concentrations exceeded 2 $\mu \mathrm{M}$. The inhibition isotherm for $\alpha$-BuTX (Fig. 7) was adequately fit by assuming an $\mathrm{IC}_{50}$ of $9 \mu \mathrm{M}$. Thus, $\alpha$-BuTX does not have a high affinity for ${ }^{125}$ I-n-BuTX binding sites in the ganglion. Because of uncertainty about whether binding to both high- and low-affinity sites is adequately represented in experiments at a single concentration of ${ }^{125} \mathrm{I}-\mathrm{n}$-BuTX (5 nM), we compared Scatchard plots of binding of ${ }^{125} \mathrm{I}-\mathrm{n}$-BuTX in the presence and the absence of $1 \mu \mathrm{M} \alpha$-BuTX. Both high- and low-affinity binding sites for ${ }^{125} I$-n-BuTX were present when $1 \mu \mathrm{M} \alpha$-BuTX was included in the incubation, and the values of $K_{d, a p p}$ and $B_{\max }$ for both of these sites were not significantly different from means computed in the absence of $\alpha$-BuTX (high-aftinity site: $K_{d, \mathrm{app}}=$ $1.9 \pm 1.0 \mathrm{nM}, B_{\max }=2.3 \pm 0.9 \mathrm{fmol} /$ ganglion; low-affinity site: $K_{d, \text { app }}-3.7 \pm 6.8 \mu \mathrm{M}, B_{\max }=5.2 \pm 9.8 \mathrm{pmol} /$ ganglion; $n=4$; $p>0.6$ by Mann-Whitney test). Thus, $\alpha$-BuTX at $1 \mu \mathrm{M}$ does not appear to interfere with the binding of ${ }^{125} \mathrm{I}-\mathrm{n}$-BuTX to either the high- or the low-affinity binding site. The effect of concentrations of $\alpha$-BuTX in excess of $2 \mu \mathrm{M}$ (Fig. 7) may be due to the presence of minute amounts of contaminating n-BuTX in commercially prepared samples of $\alpha$-BuTX (Couturier et al., 1990). The concentration of unlabeled n-BuTX that blocks half the binding of $5 \mathrm{nM}{ }^{125} \mathrm{I}-\mathrm{n}-\mathrm{BuTX}$ is approximately $50 \mathrm{nM}$ (Fig. 6), and thus inhibition of binding by $\alpha$-BuTX could be explained if $0.5 \%$ of the molecules in the sample of $\alpha$-BuTX are actually n-BuTX. 

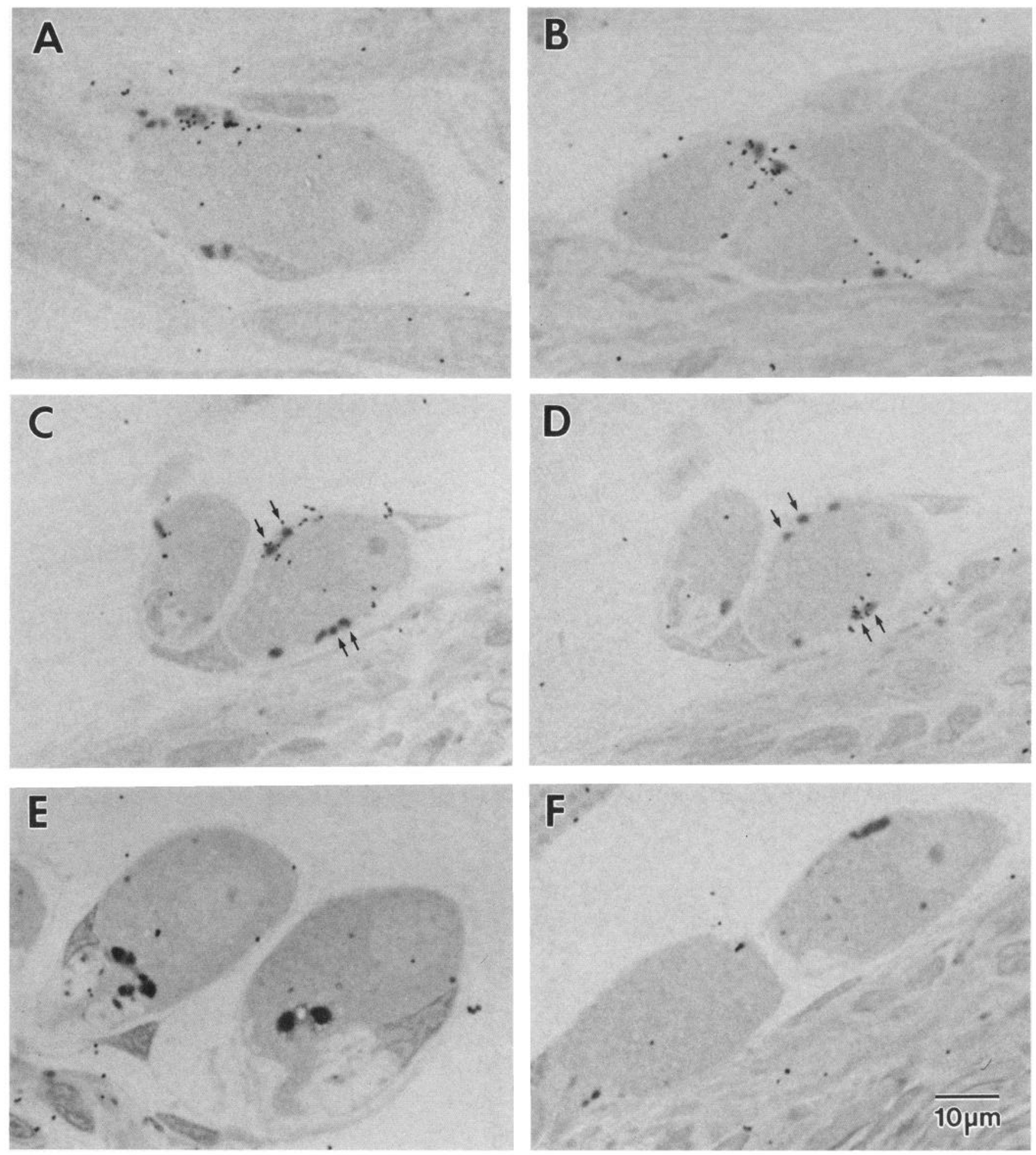

Figure 8. Autoradiograms of cardiac ganglion cells labeled with ${ }^{125}$ I-n-BuTX. Ganglion cells were photographed by double exposure, with one focal plane at the plastic section and one focal plane in the overlying emulsion. Autoradiographic grains appear as black dots, and synaptic boutons as stained areas at the cell perimeter. $A-D$, Cells incubated with $20 \mathrm{nM}^{125} \mathrm{I}-\mathrm{n}$-BuTX alone ( $C$ and $D$ are of the same cells in near serial sections), while $E$ and $F$ show cells from a ganglion incubated simultaneously with 20 nм ${ }^{125}$ I-n-BuTX and $2 \mu \mathrm{M}$ unlabeled n-BuTX. Arrows in $C$ and $D$ illustrate individual stained boutons visible in both sections but labeled with grains in only one. The distribution and number of grains were analyzed after drawing the neuronal perimeter and the location of significant boutons and autoradiographic grains using a camera lucida attachment to a compound microscope (see Fig. 1). Scale bar (in $F$ ), $10 \mu \mathrm{m}$. 
The high-affinity binding site for ${ }^{125} \mathrm{I}-\mathrm{n}-\mathrm{BuTX}$ is a strong candidate for the functional nicotinic AChR, since its $K_{d, \text { app }}$ is similar to the concentration needed to block an appreciable fraction of the functional AChRs.

\section{Binding of ${ }^{125} I-n B u T X$ to intact cardiac ganglia}

Light microscopic autoradiography was used to demonstrate that ${ }^{125} \mathrm{I}-\mathrm{n}$-BuTX bound selectively at synaptic sites on the surface of ganglion cells at a concentration that blocked functional AChRs (20 nM; Fig. 8). When incubations included $2 \mu \mathrm{M}$ unlabeled n-BuTX in addition to $20 \mathrm{nM}{ }^{125} \mathrm{I}-\mathrm{n}$-BuTX, grain density at synaptic sites was reduced to $3 \%$ of the density in its presence. The specific grain density at synaptic sites was 15 -fold greater than that at extrasynaptic sites (mean of seven experiments). Another measure of the distribution of grains was provided by noting the location of grain clusters. A cluster was defined arbitrarily as occurring whenever grain density within a window appropriate for an average-sized synaptic bouton was at least five times greater than the average surface grain density for the entire cell perimeter. Using this criterion, $24 \%$ of all boutons were found to contain clusters of grains ( 83 of 353 boutons examined in seven experiments), and $63 \%$ of all grain clusters were found at boutons ( 83 of 132 clusters). Boutons thus account for nearly two-thirds of the grain clusters despite occupying only $3 \%$ of the cell surface (McMahan and Kuffler, 1971). This corresponds to a 21 -fold enrichment of clusters at boutons, which parallels the 15-fold increase in specific grain density at synaptic sites. The concentration of grains at synaptic sites suggests that ${ }^{125} \mathrm{I}-\mathrm{n}$-BuTX is binding to AChRs, which are known to be concentrated there (Harris et al., 1971; Sargent and Pang, 1989).

While some boutons had many grains, others had none (Fig. 8 ). The average number of grains per bouton for all experiments was 3.2 , but approximately $30 \%$ of the boutons had no grains at all (101 of 353). Variability in the degree of labeling is present at the level of single boutons, which in Figure 8, $C$ and $D$, are visible in adjacent $0.5 \mu \mathrm{m}$ sections but are labeled in only one. This variability is not likely to result from the stochastic nature of isotope decay, since several grains are present when boutons are labeled. The variability in bouton labeling presumably arises because AChRs are concentrated beneath active zones, which occupy only $12 \%$ of the bouton contact area (Sargent and Pang, 1989). Thus, many semithin plastic sections passing through boutons will presumably miss the sites of highest AChR density.

${ }^{125} \mathrm{I}-\mathrm{n}$-BuTX bound also to the nonsynaptic surface of the membrane; average extrasynaptic grain density was $0.08 \pm 0.03$ grains $/ \mu \mathrm{m}$ for seven experiments and was reduced to $0.03 \pm$ 0.01 grains $/ \mu \mathrm{m}$ when incubations contained excess unlabeled $\mathrm{n}$-BuTX $(p=0.0013)$. This suggests that there are extrasynaptic AChRs on the surface of ganglion cells and complements earlier immunocytochemical results indicating that there are AChR clusters in the extrasynaptic membrane of cardiac ganglion cells (Sargent and Pang, 1989). Extrasynaptic surfaces of the ganglion cell accounted for $37 \%$ of the clusters of grains ( 50 of 132 , defined as before), many of which presumably correspond to the $\mathrm{AChR}$ clusters noted by immunocytochemical techniques (Sargent and Pang, 1989). Some of the extrasynaptic binding of ${ }^{125}$ I-n-BuTX may also be diffusely distributed AChRs.

Autoradiographic grains within neurons (Fig. 8) may result from internalization of surface-bound ${ }^{125} \mathrm{I}-\mathrm{n}$-BuTX during the incubation period (Loring and Zigmond, 1987). Internal grains presumably do not result from ${ }^{125}$ I-n-BuTX binding directly to internal receptors, since experiments were done on intact, un-
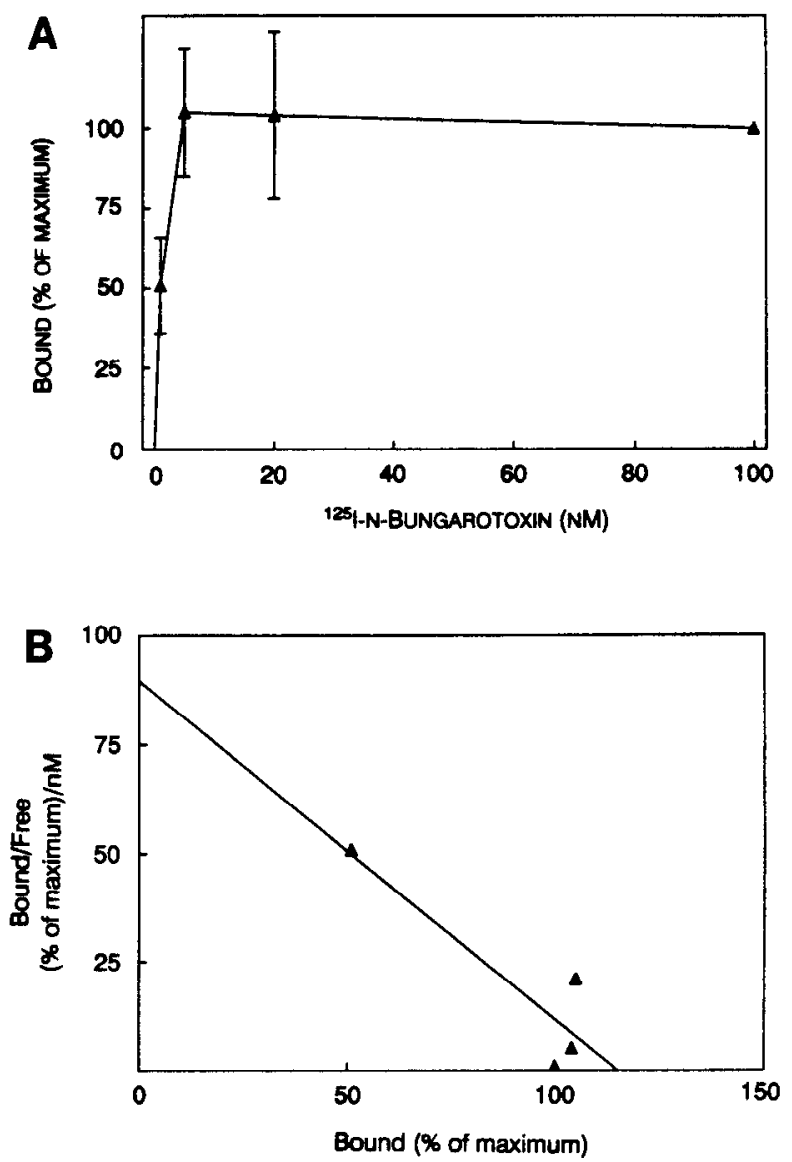

Figure 9. Specific binding of ${ }^{125}$ I-n-BuTX to the synaptic surface of ganglion cells apparently displays a single class of high-affinity binding sites. Specific binding $(A)$, given as mean \pm SE for three experiments, saturates at less than $5 \mathrm{nM}$. Scatchard analysis $(B)$ suggests that there may be only a single class of binding sites, the $K_{d, \text { app }}$ for which is estimated to be $1.3 \mathrm{~nm}$. Autoradiograms were exposed for different periods of time for each concentration (ranging typically from 10 to $40 \mathrm{~d}$ ). Calculations of relative grain density were made by assuming that the sensitivity of the emulsion did not change during the course of the experiment (i.e., by ignoring latent image fading).

fixed tissue. The number of grains at least $6 \mu \mathrm{m}$ within the perimeter of the cell, and presumably not the result of isotope decay from surfacc-bound ligand, was $0.8 \pm 0.5$ per cell in experimental preparations and $0.3 \pm 0.3$ per cell in control preparations containing excess unlabeled $\mathrm{n}-\operatorname{BuTX}(n=8)$. These two means are not statistically different, however $(p=0.065)$ and internalization of bound ${ }^{125} \mathrm{I}-\mathrm{n}$-BuTX by this assay was therefore undetectable in our experiments.

The binding of ${ }^{125}$ I-n-BuTX to the surface of ganglion cells displays high affinity, as revealed when the effect of varying the concentration of ${ }^{125}$ I-n-BuTX was noted upon grain density. Synaptic and extrasynaptic grain densities were determined after incubating intact ganglia with $1,5,20$, and $100 \mathrm{nM}{ }^{125} \mathrm{I}-\mathrm{n}$-BuTX. The pooled results demonstrate that binding of ${ }^{225}$ I-n-BuTX to synaptic membrane is saturable and occurs with high affinity (Fig. 9). The $K_{\text {dapp }}$ for binding to synaptic sites cannot be estimated accurately due to the small number of points but probably falls between 1.0 and $2.0 \mathrm{~nm}$ (mean, $1.3 \mathrm{~nm}$; range is mean \pm $95 \%$ confidence limits; symmetry about the mean is preserved when values are given as slopes and not inverted to yield $K_{d, \text { app }}$ estimates). Similar results were obtained for binding of ${ }^{125}[-n-$ 


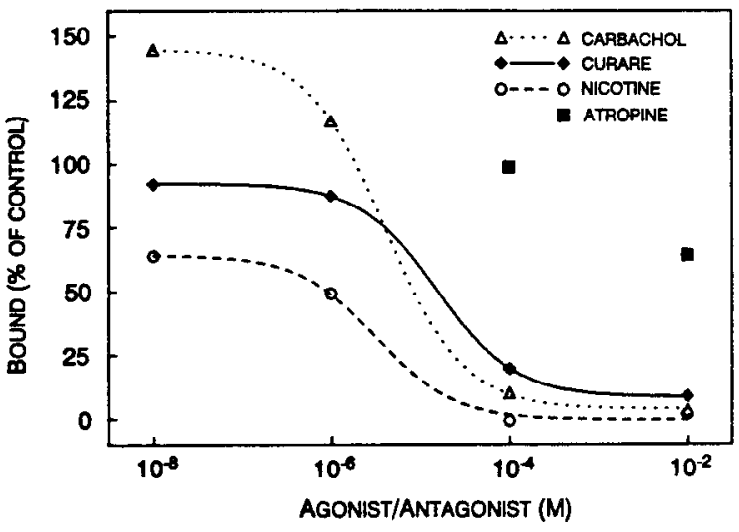

Figure 10. Binding of $20 \mathrm{nM}^{125} \mathrm{I}-\mathrm{n}-\mathrm{BuTX}$ to synaptic sites is blocked by $d$-tubocurarine (curare), nicotine, and carbachol, but not by atropine. Ganglia were preincubated with agonist/antagonist for $20 \mathrm{~min}$ and then coincubated along with $20 \mathrm{nM}{ }^{125} \mathrm{I}-\mathrm{n}$-BuTX for $1 \mathrm{hr}$. Data are given as the specific binding at synaptic sites measured in a single experiment. Binding is expressed as the percentage of maximal binding (obtained in the absence of agonist or antagonist), with $0 \%$ indicating the binding observed in the presence of $2 \mu \mathrm{M}$ unlabeled n-BuTX. None of the means at $10^{-8} \mathrm{M}$ differed significantly from $100 \%$, and none of the means at $10^{-2} \mathrm{M}$ differed significantly from $0 \%$ except atropine. Data were analyzed by ANOVA. Fitted curves had $\mathrm{IC}_{50}$ values given in the Results.

BuTX to extrasynaptic membrane, where the $K_{d \text {,app }}$ was estimated to be between 0.9 and $5.0 \mathrm{~nm}$ (mean, $1.5 \mathrm{nM}$ ). These estimates are not significantly different from the calculated dissociation constant for the high-affinity binding site characterized in tissuc homogenates (mean, $1.7 \mathrm{~nm} ; p>0.3$ ) and indicate that surface binding to ganglion cells represents part or all of the high-affinity sites characterized in homogenates.

Binding of ${ }^{125} \mathrm{I}-\mathrm{n}$-BuTX to synaptic sites is inhibited by cholinergic agonists and antagonists (Fig. 10). In these experiments, intact ganglia were preincubated with agonist/antagonist for 20 min and then coincubated with agonist/antagonist plus $5 \mathrm{~nm}$ ${ }^{125} \mathrm{I}-\mathrm{n}$-BuTX for $1 \mathrm{hr}$. Incubations were limited to $1 \mathrm{hr}$ to increase the likelihood of observing an effect of agents that probably do not have an affinity for the AChR as great as that of $n$-BuTX. Carbachol $\left(\mathrm{IC}_{50} \cong 4 \mu \mathrm{M}\right), d$-tubocurarine $\left(\mathrm{IC}_{50} \cong 16 \mu \mathrm{M}\right)$, and nicotine $\left(\mathrm{IC}_{50} \cong 3 \mu \mathrm{M}\right)$ were fairly effective in blocking binding of ${ }^{125} \mathrm{I}-\mathrm{n}$-BuTX, while atropine was not effective $\left(\mathrm{IC}_{50}>10 \mathrm{~mm}\right)$. These $\mathrm{IC}_{50}$ values were obtained using only four different concentrations of agonist/antagonist and in a single experiment and should be regarded only as rough estimates.

\section{Effects of denervation}

Cardiac ganglia denervated for 2-3 weeks display two classes of binding sites for ${ }^{125}$ I-n-BuTX (Fig. 11). The means from seven separate determinations indicate that the high-affinity binding site for ${ }^{125 I-n-B u T X}$ has a $K_{d, \text { app }}$ of $2.1 \pm 1.9 \mathrm{nM}$ and a $B_{\max }$ of $5.2 \pm 4.2 \mathrm{fmol} /$ ganglion, and the low-affinity binding site, a $K_{d \text {,app }}$ of $7.5 \pm 5.0 \mu \mathrm{M}$ and $\mathrm{a} B_{\max }$ of $6.0 \pm 4.9 \mathrm{pmol} / \mathrm{ganglion}$. None of these means is significantly different from those obtained for normal ganglia (Mann-Whitney test, $p>0.6$ ). These results suggest that the same two classes of binding sites for ${ }^{125} I$ $\mathrm{n}$-BuTX are present in denervated ganglia and in normal ganglia and that denervation does not significantly alter the number of sites in either class. The protein content of the ganglion was not altered by denervation ( $p=0.26$ by Mann-Whitney test; see also Streichert and Sargent, 1990), and thus denervation of the

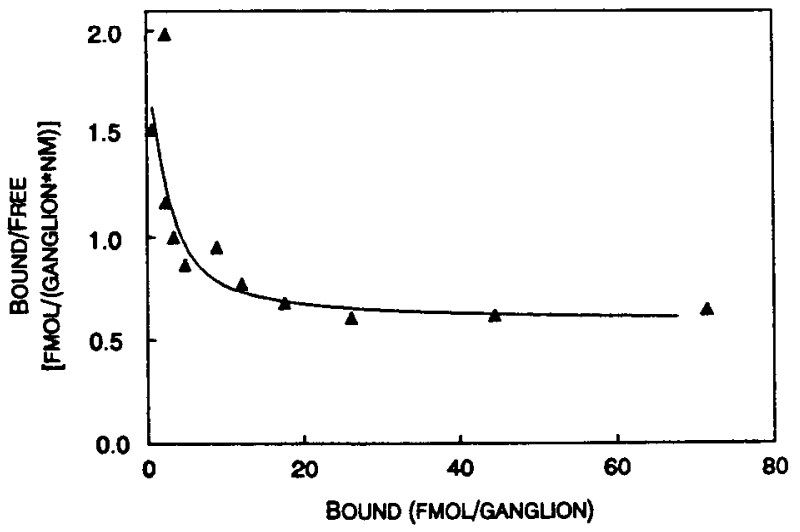

Figure 11. Scatchard plot for binding of ${ }^{125}$ I-n-BuTX to homogenates of denervated cardiac ganglia displays two classes of binding sites. These data, taken from a single experiment, are adequately fit by assuming a high-affinity binding site with a $K_{d, \text { app }}$ of $2.1 \mathrm{nM}$ and a $B_{\max }$ of $2.6 \mathrm{fmol} /$ ganglion and a low-affinity binding site with a $K_{d, \mathrm{app}}$ of $7.8 \mu \mathrm{M}$ and a $B_{\max }$ of $4.6 \mathrm{pmol} / \mathrm{ganglion}$. The means for these parameters, taken from eight separate determinations, were not significantly different from the means derived from normal ganglia (see Results).

cardiac ganglion does not significantly alter the number of highaffinity or low-affinity sites per microgram of protein.

The extent of binding of ${ }^{125} \mathrm{I}-\mathrm{n}-\mathrm{BuTX}$ to the surface of denervated ganglion cells (Fig. 12) was comparable to that observed in normal ganglia analyzed in parallel, as determined by comparing surface grain density in the two conditions. The mean surface grain density in denervated ganglia was $92 \pm 39 \%$ of normal ganglia, averaged over eight experiments (not significantly different from $100 \% ; p=0.58$ by Wilcoxon signed-rank test). The average cell perimeter did not change upon denervation $(p=0.96)$, and denervation did not alter the number of grains per ganglion cell perimeter.

The distribution of grains on the surface of denervated ganglion cells was nonuniform. If a cluster of grains is defined as occurring when the grain density is at least five times the mean grain density within a window corresponding to an averagesized bouton, then the incidence of clusters in denervated ganglia, $0.60 \pm 0.26$ per cell perimeter, was comparable to the incidence in normal ganglia, $0.65 \pm 0.19(n=7$ experiments; $p=0.69$ ). This result was unexpected in light of the fact that high-density patches of AChRs visualized immunocytochemically tend to be randomly distributed over the surface of denervated neurons, whereas they are highly clustered in normal ganglia (Sargent and Pang, 1988). The prediction based on these immunocytochemical findings is that there should be less clustering of autoradiographic grains on denervated neurons than on normal ones. It is difficult to rule out the possibility that some of these clusters are induced by ligand binding (see Discussion). The actual distribution of AChRs on the cell surface could, in theory, be determined by fixing the tissue before incubating it with ${ }^{125} \mathrm{I}-\mathrm{n}$-BuTX. Unfortunately, however, even low concentrations of formaldehyde $(0.5 \%)$ eliminate the specific binding of ${ }^{125}$ I-n-BuTX to synaptic sites in the cardiac ganglion.

If $\mathrm{AChR}$ distribution is altered by incubation with ${ }^{125} \mathrm{I}-\mathrm{n}$ BuTX, then the possibility arises that AChRs have been internalized during the incubation period. The number of surface AChRs may be sustained during the incubation by replacement from internal stores, in which case internalization should not affect the comparison of AChRs on normal and denervated cells. 

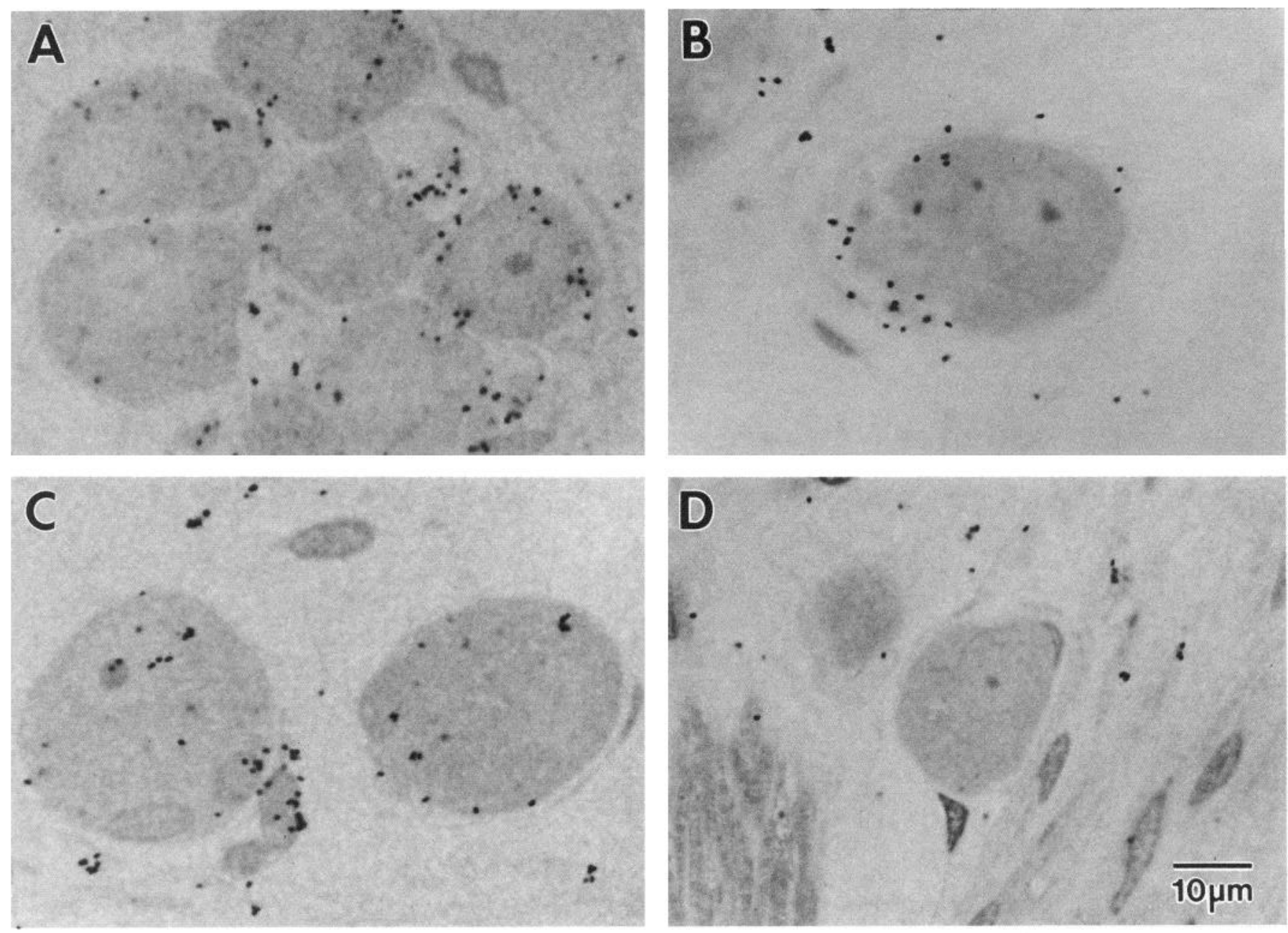

Figure 12. Autoradiogram of denervated cardiac ganglion cells incubated with ${ }^{125}$ I-n-BuTX and subsequently stained immunocytochemically for synaptic boutons. No boutons are visible, since the cells are denervated. $A-C$, Cells from septa incubated with $20 \mathrm{~nm}{ }^{125} \mathrm{I}-\mathrm{n}-\mathrm{BuTX}$ alone, while $D$ shows a cell from a septum incubated simultaneously with ${ }^{125}$ I-n-BuTX and $2 \mu \mathrm{M}$ unlabeled n-BuTX. Scale bar (in $D$ ), $10 \mu \mathrm{m}$.

If internalized AChRs are not replaced, the comparison of surface AChRs might be confounded if the rate of internalization were different for normal and denervated cells. Under these conditions, it would be more appropriate to compare total grains per cell (internal plus surface); however, denervated and normal cells do not differ when their total grain number is compared $(p=0.36)$. Thus, denervation does not significantly change the number of AChRs associated with ganglion cells, even when the possibility of ligand-induced downregulation of surface $\mathrm{AChRs}$ is taken into account.

\section{Discussion}

$n$-BuTX is a ligand for the nicotinic acetylcholine receptor in the cardiac ganglion

n-BuTX reversibly blocks synaptic transmission in the frog cardiac ganglion at concentrations in the nanomolar range. The effects of n-BuTX cannot be ascribed to an action upon input resistance or resting potential, since neither was altered in its presence. $\mathrm{n}$-BuTX reduces the ganglion cell response to pipettereleased ACh by more than $75 \%$ at $20 \mathrm{nM}$, and thus its principal effect on synaptic transmission is due to a postsynaptic blockade of AChRs. n-BuTX also blocks AChR function in the chick ciliary ganglion at concentrations in the $10-100 \mathrm{~nm}$ range (Ravdin and Berg, 1979; Chiappinelli, 1983; Loring et al., 1984).

Roper (1976) has estimated that the average safety factor for synaptic transmission in the mudpuppy cardiac ganglion is 3 . If the safety factor in frog ganglia is comparable to that in mudpuppy, then more than two-thirds of the AChRs must be blocked before transmission becomes subthreshold. Since 5 nм n-BuTX renders synaptic transmission subthreshold, it presumably blocks more than two-thirds of the AChRs. Therefore, physiological studies suggest that the concentration of n-BuTX needed to block half the AChRs in the cardiac ganglion is less than $5 \mathrm{nM}$. This crude estimate, coupled with the measurable reversibility of the toxin's effect on synaptic transmission (see also Ravdin and Berg, 1979; Chiappinelli, 1983), suggests that the affinity of n-BuTX for the nicotinic AChR in the cardiac ganglion, although reasonably high, is considerably lower than that of $\alpha$-toxins for nicotinic AChRs in skeletal muscle, where the halftime for dissociation may exceed the half-life of the AChR. Despite the reduced affinity of n-BuTX for nicotinic AChRs on autonomic neurons, the toxin has proven to be a useful ligand for binding and autoradiographic analyses (e.g., Halvorsen and Berg, 1986; Loring and Zigmond, 1987; Wolf et al., 1988; present study). 


\section{Binding sites for ${ }^{225} I-n-B u T X$ in homogenates of cardiac ganglia}

Scatchard analyses of the binding of ${ }^{125} \mathrm{I}-\mathrm{n}-\mathrm{BuTX}$ to cardiac ganglion homogenates indicate the presence of two classes of binding sites, a high-affinity site with a $K_{d, \text { app }}$ of $1.7 \mathrm{nM}$ and a low-affinity site with a $K_{d \text {,app }}$ of approximately $12 \mu \mathrm{M}$. The estimate of $1.7 \mathrm{~nm}$ for the high-affinity site is similar to estimates for a high-affinity ${ }^{125}$ I-n-BuTX binding site in cultures of chick ciliary ganglion neurons (5.2 nM; Halvorsen and Berg, 1986) as well as in membranes from chick optic lobe ( $1 \mathrm{~nm}$; Wolf et al., 1988), chick retina (2-7 nM; Loring et al., 1989), rat striatum (4.6 nM; Schulz et al., 1991), and human frontal cortex (1.2 nM; Sugaya et al., 1990).

The estimate of the $K_{d, \text { app }}$ for the low-affinity site is subject to considerable error, since the highest concentration of ${ }^{125} \mathrm{I}-\mathrm{n}-\mathrm{BuTX}$ used in the binding studies, $120 \mathrm{nM}$, is only $1 \%$ of the estimated $K_{d, \text { app }}$ for this site. If iodination of n-BuTX does not alter its affinity for its receptor(s), then the same two classes of binding sites should be revealed when the binding of a fixed amount of ${ }^{125} \mathrm{I}-\mathrm{n}$-BuTX is displaced by increasing concentrations of unlabeled n-BuTX. Such an inhibition curve is indeed best fit by assuming that there are two classes of binding sites for n-BuTX, having $K_{d, \text { app }}$ values of $2.4 \mathrm{~nm}$ and $70 \mathrm{~nm}$. The fact that the estimated $K_{d, \text { app }}$ for the high-affinity site is similar to that estimated from the Scatchard analysis suggests that iodination of the toxin does not reduce its affinity for the AChR. The actual $K_{d, \text { app }}$ for the low-affinity binding site is likely to be closer to 70 $\mathrm{nM}$ than to $12 \mu \mathrm{M}$, given the larger error associated with the estimate based on the Scatchard analysis.

The high-affinity site for n-BuTX binding in the cardiac ganglion is likely to represent the nicotinic $\mathrm{AChR}$, since comparable concentrations of $\mathrm{n}-\mathrm{BuTX}$ are required to half-saturate both the high-affinity binding site and the functional AChR. The number of high-affinity sites, $3.8 \mathrm{fmol}$ per ganglion, is equivalent to 2.3 $\times 10^{6}$ sites per neuron, assuming that there are 1000 neurons in the ganglion (Dennis and Sargent, 1978) and that the highaffinity sites are restricted to neurons. If individual AChRs each bear two binding sites for ${ }^{125} I-n-B u T X$, and if one-third of the AChRs are present on the cell surface (Stollberg and Berg, 1987), then the average surface AChR density is approximately 400/ $\mu \mathrm{m}^{2}$, assuming that AChRs are restricted to the cell body. This estimate would predict unreasonably high $\mathrm{AChR}$ densities at sites of clustering $\left(>30,000 / \mu \mathrm{m}^{2}\right)$ if the density there were 100 fold higher than elsewhere on the surface (see Appendix for calculation of the degree of enrichment of AChRs in clusters). The calculated average AChR density would be less than 400/ $\mu \mathrm{m}^{2}$ if there were high-affinity ${ }^{125} \mathrm{I}-\mathrm{n}-\mathrm{BuTX}$ binding sites on ganglion cell axons and/or on cells other than neurons.

The identity of the low-affinity binding site for n-BuTX is unknown. A low-affinity binding site for n-BuTX has been found in chick retina (Loring et al., 1989) and in human brain (Sugaya et al., 1990), but no satisfactory explanation has yet been offered for the source of these sites nor for their function. I The large 3000-fold excess of low-affinity sites over high-affinity sites in the frog cardiac ganglion makes it unlikely that the low-affinity site represents internal AChRs within ganglion cells that have not been fully assembled and that have a reduced affinity for $n$ BuTX. The autoradiographic data indicate that low-affinity binding sites for n-BuTX are not present on the surface of ganglion cells, and they may be associated with some other cell type within the ganglion.
$\alpha$-BuTX at $300 \mathrm{nM}$ does not block ACh responses elicited from ganglion cells, nor does it appear to bind either of the sites recognized by $n$-BuTX. The failure of $\alpha$-BuTX to interfere with $\mathrm{AChR}$ function is consistent with the results in the chick ciliary ganglion (Ravdin and Berg, 1981; Chiappinelli, 1983; Loring et al., 1984). However, the failure of $\alpha-B u T X$ to recognize a binding site also recognized by $\mathrm{n}-\mathrm{BuTX}$ contrasts with the situation in the ciliary ganglion, wherc one of the two high-affinity sites recognized by $n-B u T X$ is also recognized with high affinity by $\alpha$-BuTX (Halvorsen and Berg, 1986; Loring and Zigmond, 1987). In Scatchard analyses, we found that the mean number of highaffinity sites for ${ }^{125} \mathrm{I}-\mathrm{n}-\mathrm{BuTX}$ was reduced by $\cong 40 \%$ in the presence of $1 \mu \mathrm{M} \alpha$-BuTX but that this reduction was not statistically significant. If this effect is not the result of n-BuTX contamination in our samples of $\alpha$-BuTX, then the possibility remains that some of the high-affinity sites recognized by n-BuTX are also recognized by $\alpha$-BuTX, but that this event remains undetectable due to the large coefficient of variation in our measurements of $B_{\max }(0.4)$.

The failure of $300 \mathrm{~nm} \alpha$-BuTX to block AChR function in the cardiac ganglion apparently differs from the results of Marshall (1981), who found that $\alpha$-BuTX blocked AChR function on bullfrog lumbar sympathetic neurons. Marshall found that $100 \mathrm{nM} \alpha$-BuTX had no cffect upon the fast EPSPs elicited from ganglion cells by preganglionic nerve stimulation but that $1-5$ $\mu \mathrm{M}$ blocked EPSPs (and carbachol responses) reversibly. It is conceivable that we would have seen an effect of $\alpha$-BuTX at $1-$ $5 \mu \mathrm{M}$. However, such an effect could be caused by contaminating $\mathrm{n}$-BuTX if only one molecule out of $200(0.5 \%)$ in the $\alpha$-BuTX sample were n-BuTX. It remains a possibility that $\alpha$-BuTX recognizes AChRs on bullfrog sympathetic neurons (Marshall, 1981), but the ligand for AChRs that underlie synaptic function in the parasympathetic cardiac ganglion is clearly n-BuTX and not $\alpha$-BuTX.

\section{Distribution of AChRs on normally innervated ganglion cells}

Binding of ${ }^{125} \mathrm{I}-\mathrm{n}-\mathrm{BuTX}$ to the surface of cardiac ganglion cells, as measured by autoradiography, is saturable and occurs with an affinity comparable both to that of the high-affinity site characterized in homogenates and to that of the functional AChR. Surface binding is concentrated at synaptic sites and is antagonized by carbachol, nicotine, and $d$-tubocurarine. The evidence therefore indicates that surface binding of ${ }^{125} I-n-B u T X$ is to the nicotinic $\mathrm{AChR}$. We found no evidence for a low-affinity binding site on the surface of ganglion cells. If low- and high-affinity sites were present on the cell surface at the same ratio as found in the ganglion as a whole, then there should be 4.4 times more binding on the surface in the presence of $100 \mathrm{nM}{ }^{125} \mathrm{I}-\mathrm{n}-\mathrm{BuTX}$ than in the presence of $20 \mathrm{~nm}{ }^{125} \mathrm{I}-\mathrm{n}-\mathrm{BuTX}$. However, we found no increment in binding at $100 \mathrm{~nm}^{125} \mathrm{I}-\mathrm{n}-\mathrm{BuTX}$ (Fig. 9). We think it unlikely that low-affinity sites were missed on the cell surface because ${ }^{125} \mathrm{I}-\mathrm{n}$-BuTX dissociated from them during the 15 min of washout preceding fixation. Such a rapid dissociation $\left(t_{1 / 2} \ll 15 \mathrm{~min}\right.$ ) should have virtually eradicated the low-affinity site in the binding assays, where the interval between dilution of the assay medium and separation of bound from free ${ }^{125} I-n-$ BuTX is approximately $10 \mathrm{~min}$.

Autoradiographic evidence indicates that AChRs are concentrated at synaptic sites on the ganglion cell surface. Harris et al. (1971) found that the ACh chemosensitivity of synaptic regions was greater than that of randomly chosen sites on the surface of frog cardiac ganglion cells, but the inability to quantify the 
iontophoretic technique and uncertainties about the effects of a nonuniform distribution of AChE has left unresolved the extent to which AChRs are concentrated in the synaptic membrane. The average synaptic grain density in the present study was 15 times greater than the average extrasynaptic grain density. However, only about $10 \%$ of the ganglion cell surface contacted by boutons has high-density clusters of AChRs, as defined by the appearance of peroxidase stain after AChRs have been visualized with an anti-AChR antibody and the $\mathrm{ABC}$ immunoperoxidase technique (Sargent and Pang, 1989). The contribution of this $10 \%$ has been averaged over the entire bouton contact zone in the current analysis, and therefore the difference in AChR density between the AChR-rich region of the synaptic membrane and the extrasynaptic membrane may be closer to 150 fold than 15 -fold. This speculation is consistent with the detailed studies of Loring, Zigmond, and others, who used EM autoradiography to study the distribution and density of ${ }^{125 I-n-B u T X}$ binding sites both in the chick ciliary ganglion (Loring and Zigmond, 1987) and in cultured rat sympathetic neurons (Loring et al., 1988). In both instances, the density of binding sites was considerably grcater at synaptic sites; in the chick system the difference in density was $10-40$-fold, while for rat sympathetic neurons it was at least 80 -fold.

The fact that labeling of cell surface AChRs was performed in unfixed ganglia raises the possibility that AChR distribution may be altered as a result of binding of ${ }^{125} I-n-B u T X$. n-BuTX exists as a dimer in solution (Chiappinelli and Lee, 1985), and the neuronal nicotinic AChR is thought to contain two binding sites for n-BuTX (Lindstrom et al., 1987), which are located on its $\alpha$-subunits. If the active form of n-BuTX is the dimer, and if a single dimer can cross-link two AChR molecules, then incubation of living cells with n-BuTX can conceivably result in a ligand-induced clustering of AChRs that would ordinarily be diffusely distributed. It seems unlikely that many of the grain clusters at synaptic sites are the result of such a ligand-induced clustering, since there is ample independent evidence that $\mathrm{AChRs}$ are concentrated at synaptic sites (Harris et al., 1971; Sargent and Pang, 1989; see also Marshall, 1981; Jacob et al., 1986; Loring and Zigmond, 1987). It is possible, though, that some of the extrasynaptic grain clusters are the result of ligand-induced aggregation of AChRs. Using immunocytochemical techniques and electron microscopy on fixed tissue, we previously found that $21 \%$ of the AChR clusters on the surface of the ganglion cell are located extrasynaptically (Sargent and Pang, 1989). It is difficult to say whether the incidence of extrasynaptic grain clusters seen in the present work (37\%) is significantly greater than that seen previously and, if so, whether the discrepancy is due to differences in the method of analysis or, alternatively, to ligand-induced $\mathrm{AChR}$ clustering.

Although the average grain density at synaptic sites is 15 -fold greater than that at extrasynaptic sites, only $3 \%$ of the cell surface is synaptic. Thus, approximately $70 \%$ of the toxin binding sites on the cell surface are extrasynaptic $[0.97 x /(0.97 x+0.03 * 15 x)$ $=0.68$, where $x=$ the extrasynaptic grain density]. Some of these sites are presumably represented by extrasynaptic clusters of AChRs (Sargent and Pang, 1989). However, only 13\% of the total surface area of AChR clusters is extrasynaptic (Sargent and Pang, 1989); extrasynaptic AChR clusters could account for all of the extrasynaptic toxin binding sites only if the density of AChRs within them were seven times that within synaptic AChR clusters. If the density of AChRs in clusters is similar in both synaptic and extrasynaptic locations, then one can calculate that
(1) roughly one-third of the surface AChRs are clustered and two-thirds are diffuse, and (2) the density of AChRs in regions of membrane where they are clustered is on the order of 100fold higher than that in regions of membrane lacking clusters (see Appendix).

\section{Effect of denervation upon AChR number in the cardiac ganglion}

$\mathrm{n}$-BuTX at $20 \mathrm{~nm}$ reduces $\mathrm{ACh}$ responses elicited from denervated ganglion cells by nearly $90 \%$. This suggests that $n$-BuTX recognizes a majority of the functional AChRs on denervated neurons. It is still pussible that denervation leads to the expression of novel classes of AChRs not recognized by n-BuTX (Wada et al., 1988; Duvoisin et al., 1989; Sorenson and Chiappinelli, 1990), but the appearance of such AChRs cannot readily explain denervation supersensitivity to $\mathrm{ACh}$.

Denervation does not change the total number of $\mathrm{AChRs}$ in the cardiac ganglion, as determined by binding studies on homogenates using ${ }^{125} \mathrm{I}-\mathrm{n}-\mathrm{BuTX}$, nor does it change the number of AChRs on the surface of the parasympathetic neurons within the ganglion, as determined by autoradiography. If internal AChRs comprise a sizable fraction of the total, then it is likely that they, too, are unchanged following denervation. Modest changes in AChR number would not be detected by these approaches, given the variability encountered from one experiment to the next. Our results differ somewhat from those reported in the chick ciliary ganglion, where denervation reduces internal stores of AChRs without having a pronounced effect upon the surface pool (Jacob and Berg, 1988).

Denervation reduces the total surface area occupied by clusters of AChRs, as defined by the presence of AChR-immunoreactive peroxidase patches, from $0.40 \%$ to $0.15 \%$ of the cell surface (Sargent and Pang, 1988). If the total number of surface AChRs remains constant after denervation, then fewer of the AChRs must be in clusters and more must be present diffusely after denervation (or at least in a form that is undetectable with the immunoperoxidase technique).

In a preliminary report (Sargent and Bryan, 1989), we stated that the number of high-affinity binding sites for ${ }^{125} \mathrm{I}-\mathrm{n}$-BuTX was significantly reduced following denervation. These conclusions were based partly on binding data collected using a slightly different experimental protocol than that used in the present study. The original binding experiments were done for $1 \mathrm{hr}$, under which conditions the binding reaction has not reached equilibrium (Fig. 4), and controls for nonspecific binding were done with $1 \mathrm{~mm}$ carbachol instead of excess unlabeled n-BuTX. We do not know whether these changes or some other unrecognized difference accounts for the difference in results. Preliminary autoradiographic data (Sargent and Bryan, 1989) also supported the conclusion that denervation decreased the number of binding sites for ${ }^{125} \mathrm{I}-\mathrm{n}$-BuTX on the ganglion cell surface. These data were obtained in four experiments, each of which revealed a modest decline in cell surface grain density after denervation. In two of four additional experiments, however, average grain density was increased after denervation, and overall, the data pooled from eight experiments did not reveal a statistically significant change in grain density.

The apparent lack of an effect of denervation upon the number of surface AChRs in the frog cardiac and chick ciliary ganglia contrasts with the situation in skeletal musclc, where denervation leads to a 20 -fold increase in the total number of surface AChRs on skeletal myofibers (Hartzell and Fambrough, 1972). 
The increasc in the number of AChRs in skclctal muscle results from a manyfold increase in the density of AChRs in the extrajunctional membrane: the density of AChRs at the original synaptic sites actually declines, albeit very slowly, over the course of weeks (Frank et al., 1975; Porter and Barnard, 1975). The effect of denervation on surface AChRs in the two autonomic ganglia studied to date resembles its effect upon junctional AChRs in skeletal muscle rather than upon the total population of AChRs.

\section{Denervation supersensitivity in the cardiac ganglion}

Denervation leads to an increase in the sensitivity of frog cardiac ganglion cells to ACh (Kuffler et al., 1971; Dennis and Sargent, 1979). Cardiac ganglion cells in mudpuppy respond similarly (Roper, 1976). Denervation supersensitivity has also been reported in the cat superior cervical ganglion when sensitivity was examined by arterial injection of $\Lambda \mathrm{Ch}$ (Brown, 1969), and in frog lumbar sympathetic ganglia when sensitivity was measured by bath application (Dunn and Marshall, 1985). However, denervation supersensitivity has not been found in response to pipette-released $\mathrm{ACh}$, either in the frog lumbar sympathetic ganglia (Dunn and Marshall, 1985) or in the chick ciliary ganglion (McEachern et al., 1989). Denervation supersensitivity in skeletal muscle is widespread and results principally from the 300-fold increase in the density of extrajunctional AChRs (Hartzell and Fambrough, 1972) and, less so, from a decline in surface AChE (McConnell and Simpson, 1976). The fact that the number of surface AChRs recognized by n-BuTX does not change after denervation of the cardiac ganglion indicates that $\mathrm{AChR}$ upregulation cannot explain denervation supersensitivity in this preparation. We have recently shown that denervation does not increase the sensitivity of cardiac ganglion cells to carbachol, an analog of $\Lambda \mathrm{Ch}$ that is resistant to hydrolysis by $\mathrm{AChE}$, nor does it increase sensitivity to $\mathrm{ACh}$ measured in the absence of extracellular AChE (Streichert and Sargent, 1991). These results, in conjuction with the findings reported here, suggest that denervation supersensitivity in the cardiac ganglion results not from a change in AChR number but rather from a reduction in the amount and/or effectiveness of extracellular AChE.

\section{Appendix}

Calculation of the relative $A C h R$ density at sites having $A C h R$ clusters and at sites lacking them

The average surface area of a ganglion cell body is $1210 \mu \mathrm{m}^{2}$ (Sargent and Pang, 1988), and 3\% of this surface is covered by synaptic boutons (McMahan and Kuffler, 1971). Quantitative analysis by EM immunocylochemistry indicates that $4.8 \mu \mathrm{m}^{2}$ of the cell body surface is occupied by AChR clusters, as indicated by the presence of immunoreactivity after staining AChRs with an anti-AChR antibody in conjunction with the $\mathrm{ABC}$ immunoperoxidase technique (Sargent and Pang, 1988). Of this $4.8 \mu \mathrm{m}^{2}, 87 \%$ is located at synaptic sites $\left(4.2 \mu \mathrm{m}^{2}\right)$ and $13 \%$ is located extrasynaptically $\left(0.6 \mu \mathrm{m}^{2}\right)$. Thus, the $36 \mu \mathrm{m}^{2}$ of synaptic membrane ( $3 \%$ of $1210 \mu \mathrm{m}^{2}$ ) is divided into $4.2 \mu \mathrm{m}^{2}$ having AChR clusters and $31.6 \mu \mathrm{m}^{2}$ lacking them, and the $1174 \mu \mathrm{m}^{2}$ of extrasynaptic membrane is divided into $0.6 \mu \mathrm{m}^{2}$ having $\mathrm{AChR}$ clusters and $1173.4 \mu \mathrm{m}^{2}$ lacking them. If the density of $\mathrm{AChRs}$ in clusters is uniform regardless of whether the cluster is synaptic or extrasynaptic, and if the density of diffuse AChRs is also uniform, then the number of AChRs in synaptic membrane divided by the number of AChRs in extrasynaptic membrane will be

$$
\frac{4.2 x+31.6 y}{0.6 x+1173.4 y}
$$

where $x=\mathrm{AChR}$ grain density at clusters, and $y=\mathrm{AChR}$ grain density elsewhere in the membrane.

The fraction of total surface grains that arise from synaptic sites is 0.32 . Setting Equation 1 equal to $(0.32 / 0.68)$ and solving for $x$ and $y$ yields $x / y=133$.

\section{References}

Boyd RT, Jacob MH, Couturier S, Ballivet M, Berg DK (1988) Expression and regulation of neuronal acetylcholine receptor mRNA in chick ciliary ganglia. Neuron 1:495-502.

Brown DA (1969) Responses of normal and denervated cat superior cervical ganglia to some stimulant compounds. J Physiol (Lond) 201: 225-236.

Burden SJ, Sargent PB, McMahan UJ (1979) Acetylcholine receptors in regenerating muscle accumulate at original synaptic sites in the absence of the nerve. J Cell Biol 82:412-425.

Chiappinelli VA (1983) Kappa-bungarotoxin: a probe for the neuronal nicotinic receptor in the avian ciliary ganglion. Brain Res 277:9-21. Chiappinelli VA, Lee JC (1985) Kappa-bungarotoxin: self association of a neuronal nicotinic receptor probe. J Biol Chem 260:6182-6186.

Chiappinelli VA, Wolf KM, DeBin JA, Holt IL (1987) Kappa-flavitoxin: isolation of a new neuronal nicotinic receptor antagonist that is structurally related to kappa-bungarotoxin. Brain Res 402:21-29.

Couturier S, Bertrand D, Matter J-M, Hernandez M-C, Bertrand S, Millar N, Valera S, Barkas T, Ballivet M (1990) A neuronal nicotinic acetylcholine receptor subunit $(\alpha 7)$ is developmentally regulated and forms a homo-oligomeric channel blocked by $\alpha$-BTX. Neuron 5:847856.

Dennis MJ, Sargent PB (1978) Multiple innervation of normal and re-innervated parasympathetic neurones in the frog cardiac ganglion. J Physiol (Lond) 281:63-75.

Dennis MJ, Sargent PB (1979) Loss of extrasynaptic acetylcholine sensitivity upon reinnervation of parasympathetic ganglion cells. J Physiol (Lond) 289:263-275.

Dennis MJ, Harris AJ, Kuffler SW (1971) Synaptic transmission and its duplication of focally applied acetylcholine in parasympathetic neurons in the heart of the frog. Proc R Soc Lond [Biol] 177:509539.

Dunn PM, Marshall LM (1985) Lack of nicotinic supersensitivity in frog sympathetic neurones following denervation. J Physiol (Lond) 363:211-225.

Duvoisin RM, Deneris ES, Patrick J, Heinemann S (1989) The functional diversity of the neuronal nicotinic acetylcholine receptors is increased by a novel subunit: $\beta 4$. Neuron 3:487-496.

Frank E, Gautvik K, Sommerschild H (1975) Cholinergic receptors at denervated mammalian motor end-plates. Acta Physiol Scand 95: 66-76.

Halvorsen SW, Berg DK (1986) Identification of a nicotinic acetylcholine receptor on neurons using an $\alpha$-neurotoxin that blocks receptor function. J Neurosci 6:3405-3412.

Harris AJ, Kuffler SW, Dennis MJ (1971) Differential chemosensitivity of synaptic and extrasynaptic areas on the neuronal surface membrane in parasympathetic neurons of the frog, tested by microapplication of acetylcholine. Proc R Soc Lond [Biol] 177:541-553.

Hartzell HC, Fambrough DM (1972) Acetylcholine receptors: distribution and extrajunctional density in rat diaphragm after denervation correlated with acetylcholine sensitivity. J Gen Physiol 60:248-262.

Jacob MH, Berg DK (1987) Effects of preganglionic denervation and postganglionic axotomy on acetylcholine receptors in the chick ciliary ganglion. J Cell Biol 105:1847-1854.

Jacob MH, Berg DK (1988) The distribution of acetylcholine receptors in chick ciliary ganglion neurons following disruption of ganglionic connections. J Neurosci 8:3838-3849.

Jacob MH, Lindstrom JM, Berg DK (1986) Surface and intracellular distribution of a putative neuronal nicotinic acetylcholine receptor. J Cell Biol 103:205-214.

Kuffler SW, Dennis MJ, Harris AJ (1971) The development of chemosensitivity in extrasynaptic areas of the neuronal surface after denervation of parasympathetic ganglion cells in the heart of the frog. Proc R Soc Lond [Biol] 177:555-563. 
Lindstrom J, Schoepfer R, Whiting P (1987) Molecular studies of the neuronal nicotinic acetylcholine receptor family. Mol Neurobiol 1: 281-337.

Loring RH, Zigmond RE (1987) Ultrastructural distribution of ${ }^{125} \mathrm{I}$ toxin $\mathrm{F}$ binding sites on chick ciliary neurons: synaptic localization of a toxin that blocks ganglionic nicotinic receptors. J Neurosci 7: $2153-2162$.

Loring RH, Chiappinelli VA, Zigmond RE, Cohen JB (1984) Characterization of a snake venom neurotoxin which blocks nicotinic transmission in the avian ciliary ganglion. Neuroscience 11:989-999.

Loring RH, Sah DWY, Landis SC, Zigmond RE (1988) The ultrastructural distribution of putative nicotinic receptors on cultured neurons from the rat superior cervical ganglion. Neuroscience 24:10711080.

Loring RH, Aizenman E, Lipton SA, Zigmond RE (1989) Characterization of nicotinic receptors in chick retina using a snake venom neurotoxin that blocks neuronal nicotinic receptor function. J Neurosci 9:2423-2431.

Marshall LM (1981) Synaptic localization of $\alpha$-bungarotoxin binding which blocks nicotinic transmission at frog sympathetic neurons. Proc Natl Acad Sci USA 78:1948-1952.

Matthew WD, Tsavaler L, Reichardt LF (1981) Identification of a synaptic vesicle-specific membrane protein with a wide distribution in neuronal and neurosecretory tissue. J Cell Biol 91:257-269.

McConnell MG, Simpson L (1976) The role of acetylcholine receptors and acetylcholinesterase activity in the development of denervation supersensitivity. J Pharmacol Exp Ther 198:507-517.

McEachern AE, Jacob MH, Berg DK (1989) Differential effects of nerve transection on the $\mathrm{ACh}$ and GABA receptors of chick ciliary ganglion neurons. J Neurosci 9:3899-3907.

McMahan UJ, Kuffler SW (1971) Visual identification of synaptic boutons on living ganglion cells and of varicosities in postganglionic axons in the heart of the frog. Proc R Soc Lond [Biol] 177:485-508.

Porter CW, Barnard EA (1975) Distribution and density of cholinergic receptors at the motor end-plates of a denervated mouse muscle. Exp Neurol 48:542-556.

Ravdin PM, Berg DK (1979) Inhibition of neuronal acetylcholine sensitivity by $\alpha$-toxins from Bungarus multicinctus venom. Proc Natl Acad Sci USA 76:2072-2076.

Roper S (1976) The acetylcholine sensitivity of the surface membrane of multiply innervated parasympathetic ganglion cells in the mud- puppy before and after partial denervation. J Physiol (Lond) 254: 455-473.

Sargent PB (1983) The number of synaptic boutons terminating on Xenopus cardiac ganglion cells is directly correlated with cell size. J Physiol (Lond) 343:85-104.

Sargent PB, Bryan GK (1989) Effect of denervation upon acetylcholine receptor number on the surface of cardiac ganglion cells. Soc Neurosci Abstr 15:497.

Sargent PB, Pang DZ (1988) Denervation alters the size, number, and distribution of clusters of acetylcholine receptor-like molecules on frog cardiac ganglion neurons. Neuron 1:877-886.

Sargent PB, Pang DZ (1989) Acetylcholine receptor-like molecules are found in both synaptic and extrasynaptic clusters on the surface of neurons in the frog cardiac ganglion. J Neurosci 9:1062-1072.

Schulz DW, Loring RH, Aizenman E, Zigmond RE (1991) Autoradiographic localization of putative nicotinic receptors in the rat brain using ${ }^{125}$ I-neuronal bungarotoxin. J Neurosci 11:287-297.

Sokal RR, Rohlf FJ (1981) Biometry, 2d ed, pp 782-787. New York: Freeman.

Sorenson EM, Chiappinelli V (1990) Intracellular recording in avian brain of a nicotinic response that is insensitive to $k$-bungarotoxin. Neuron 5:307-315.

Stollbcrg J, Bcrg DK (1987) Neuronal acetylcholine receptors: fate of surface and internal pools in cell culture. J Neurosci 7:1809-1815.

Streichert LC, Sargent PB (1990) Differential effects of denervation on acetylcholinesterase activity in parasympathetic and sympathetic ganglia of the frog Rana pipiens. J Neurobiol 21:938-949.

Streichert LC, Sargent PB (1991) The role of acetylcholinesterase in denervation supersensitivity in the frog cardiac ganglion. J Physiol (Lond), in press.

Sugaya K, Giacobini E, Chiappinelli VA (1990) Nicotinic acetylcholine receptor subtypes in human frontal cortex: changes in Alzheimer's disease. J Neurosci Res 27:349-359.

Wada K, Ballivet M, Boulter J, Connolly J, Wada E, Deneris ES, Swanson LW, Heinemann S, Patrick J (1988) Functional expression of a new pharmacological subtype of brain nicotinic acetylcholine receptor. Scicnce 240:330-334.

Wolf KM, Ciarleglio A, Chiappinelli VA (1988) $k$-Bungarotoxin: binding of a neuronal nicotinic receptor antagonist to chick optic lobe and skeletal muscle. Brain Res 439:249-258. 